\title{
Bivalves from the Middle Ordovician Šárka Formation (Prague Basin, Czech Republic)
}

\author{
MARIKA POLECHOVÁ
}

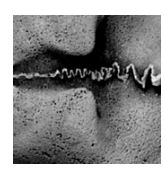

A rich bivalve fauna from the Middle Ordovician (Šárka Formation, early and mid Darriwilian) of Bohemia shows close
affinities to Middle Ordovician bivalves from Spain (Iberian Peninsula) and France (Armorican Massif). Twelve species
and nine genera (one new) are described: Praenucula applanans (Barrande, 1881), Praenucula bohemica (Barrande,
1881), Praenucula dispar (Barrande, 1881), Concavodonta ponderata (Barrande, 1881), Pseudocyrtodonta ala
(Barrande, 1881), Pseudocyrtodonta incola (Barrande, 1881), Tatula petula gen. et sp. nov., Redonia deshayesi Rouault,
1851, Babinka prima Barrande, 1881, Coxiconchia britannica (Rouault, 1851), and the oldest pteriomorphids in the
Prague Basin Modiolopsis sp. and Cyrtodonta sp. Ctenodonta, widely used as cumulative name for all praenuculids, was
not recorded in the Middle Ordovician of Bohemia. Remarks on the characters of the Protobranchia shell are discussed,
the value of the orientation of the teeth to the umbo or out from the umbo for higher systematic has been overestimated in
the past. Accessory muscle scars in the Protobranchia help to move with foot, not only by retraction and protraction but
also by elevation; some of them hold a visceral sac. The Recent Protobranchia mostly show simpler type of taxodont
teeth in comparison with the Ordovician Protobranchia. Palaeoecological aspects of all the species are shown, infaunal
burrowers dominate in the lithofacies of the black shales of the Šárka Formation. The bivalve association is dominated
numerically by heterodonts, subdominant are several species of protobranchs and two pteriomorphids. The
palaeogeographic distribution of the Middle Ordovician bivalves is discussed. Some of the Middle Ordovician bivalves
are widely distributed, they reach Baltica and also the Laurentian margins and probably had to have planktotrophic lar-
vae. Clear preference of the heterodonts for high latitude is confirmed by the dominant heterodonts (six species) in the
bivalve association of the Middle Ordovician Šrarka Formation. Key words: bivalves, Middle Ordovician, Perunica,
Bohemia, systematics, palaeoecology, palaeobiogeography.

PolechovÁ, M. 2013. Bivalves from the Middle Ordovician Šárka Formation (Prague Basin, Czech Republic). Bulletin of Geosciences 88(2), 427-461 (16 figures, 1 table). Czech Geological Survey, Prague. ISSN 1214-1119. Manuscript received March 1, 2013; accepted in revised form March 20, 2013; published online April 4, 2013; issued June 7, 2013.

Marika Polechová, Czech Geological Survey, Klárov 3, P.O. Box 85, 11821 Praha 011, Czech Republic; marika.polechova@geology.cz

Since Barrande (1881) and Pfab (1934) works Ordovician bivalves from Bohemia were for a long time overlooked group except a few systematic studies, which were published by Horný (1960), McAlester (1965), Křǐž (1995), Kř́žz \& Steinová (= Polechová) (2009), and Steinová (= Polechová) (2012). Middle Ordovician bivalve faunas from Bohemia are very similar to Middle Ordovician bivalve faunas from Spain and France, where the Ordovician bivalves have been systematically studied for a long time (e.g. Babin 1966, 1977, 1985, 1982 in Babin et al. 1982; Babin \& Gutiérrez-Marco 1985, 1991; Babin \& Beaulieu 2003). All the authors pointed out the lack of modern information about the Ordovician bivalves from Bohemia. The preparation of the new Treatise on Invertebrate Paleontology for bivalves is in progress now and therefore it is an appropriate time for undertaking revision of the Ordovician bivalves from Bohemia.
Bivalves described here come from the Śarka Formation (Kettner \& Kodym 1919) (Fig. 1). Havlíček \& Vaněk (1966) correlated the Śarka Formation with the Llanvirn, Kraft et al. (2001) supposed that the Śarka Formation is isochronous with the late Arenig-early Llanvirn. Recently Budil et al. (2011) correlated the Šrka Formation with the early and middle Darriwilian and Fatka et al. (2013) correlates the Šárka Formation with the Oretanian Regional Stage, which is almost equal to the middle Darriwilian (Bergström et al. 2008).

The Šárka Formation has been studied for almost two hundred years (Barrande 1846; Lipold \& Krejčí 1860; Krejčí 1877; Klouček 1909, 1916; Kettner \& Kodym 1919; Hanuš 1923; Bouček 1927; Kettner \& Prantl 1948; Kukal 1962, 1963; Havlíček 1961, 1967, 1980, 1981, 1982, 1998; Havlíček \& Vaněk 1966; Bouček 1973; Kraft 1974; Kraft \& Kraft 1992, 1993, 2003; Havlíček \& Fatka 1992; Vaněk 
1999; Budil et al. 2003a, 2003b, 2007; Drost et al. 2003; Fatka 2003; Chlupáč 2003; Kraft et al. 2003; Mikuláš 2003, Manda 2008 and Fatka \& Mergl 2009).

Sedimentation of the Śarka Formation in the Prague Basin began by a significant transgression, which was contemporary for peri-Gondwanan regions. The largest part of the Šarka Formation is developed in black shale facies. The formation corresponds to two graptolite biozones, the earlier with Corymbograptus retroflexus and a later zone with Didymograptus clavulus (Bouček 1973; Kraft 1974; Kraft \& Kraft 1992, 1993). Within the shales occur horizons with siliceous nodules containing a well-preserved and diverse fauna. According to Kukal (1962) these nodules were primarily of carbonate and then they were subsequently silicified. These nodules are restricted to several localities in Prague, around Rokycany and near Úvaly and Brandýs nad Labem. Black shales prevail in the central parts of the Prague Basin, while sedimentary iron ores are presented in onshore settings (Havlíček 1998) with best exposures in Ejpovice area near Pilsen.

Accumulations of volcanic and volcanoclastic rocks are connected with submarine volcanism of the Komárov Volcanic Complex (Kukal 1962). The Ordovician volcanism reached maximum activity just within the Śarka Formation.

\section{History of research of the Ordovician bivalves from Bohemia}

Barrande (1881) figured and described these species from the Šrka Formation: Babinka prima Barrande, 1881, Leda ala Barrande, 1881 (= Pseudocyrtodonta ala), Leda bohemica Barrande, 1881 (= Praenucula bohemica), Leda incola Barrande, 1881 (= Pseudocyrtodonta incola), Nucula applanans Barrande, 1881 (= Praenucula applanans), $\mathrm{Nu}$ cula dispar Barrande, 1881 (= Praenucula dispar), Nucula faba Barrande, 1881 (= Redonia deshayesi), Redonia bohemica Barrande, 1881 (= Redonia deshayesi) and Synek antiquus (= Pseudocyrtodonta ala, partim) Barrande, 1881. He allocated them to the genera Nucula, Leda and Redonia and defined the new genera Babinka and Synek.

Pfab (1934) systematically revised the species belonging to the Protobranchia Pelseneer, 1889 and reassigned some of the Barrande's species to: Praeleda Pfab, 1934, Praenucula Pfab, 1934, Pseudocyrtodonta Pfab, 1934 and mainly to Ctenodonta Salter, 1852, and some of them he left in open nomenclature. Pfab (1934) described these species from the Šárka Formation: Ctenodonta applanans (Barrande, 1881) (= Praenucula applanans), Ctenodonta bohemica (Barrande, 1881) (= Praenucula bohemica), Ctenodonta ponderata (Barrande, 1881) (= Concavodonta ponderata), Praeleda compar (Barrande, 1881) (= Praenucula bohemica), Praeleda pulchra Pfab, 1934
(= Praenucula bohemica), Praenucula dispar dispar (Barrande, 1881) (= Praenucula dispar), Praenucula dispar expansa Pfab, 1934 (= Praenucula dispar) and Pseudocyrtodonta ala (Barrande, 1881) (= Pseudocyrtodonta ala and Pseudocyrtodonta incola). Pfab (1934) was first who paid attention to the characters of the shell, like muscle scars and hinge. He recognized six hinge types according to the shape of their teeth and if the apex of the chevronshaped teeth points towards or away from the umbo. He discussed also phylogenetic relations between Ctenodonta, Praenucula and Nucula.

After Pfab (1934) only a few authors have studied the Middle Ordovician bivalves. Růžička \& Prantl (1960) designated the lectotype for Babinka prima. Horný (1960) revised Babinka prima, created the new family Babinkidae and interpreted the phylogeny of earliest bivalves from univalved molluscs through the new order Diplacophora Horný, 1960. The systematics, affinities and life habits of Babinka as an ancestral lucinid bivalve were reinterpreted by McAlester (1965). Redonia bohemica has been discussed and redescribed by Pojeta (1971), Babin (1977) and Babin \& Gutiérrez-Marco (1991). Kř́iž (1995) described a representative of the genus Coxiconchia Babin, 1966 from the Šarka Formation and contributed to the knowledge of accessory muscle scars and their function in the Protobranchia. In 1997 Kříž briefly presented some remarks about palaeoecology of the Ordovician bivalves. Steinová (= Polechová) in 2012 revised actinodontid Pseudocyrtodonta (Pfab, 1934) from the Middle and Late Ordovician of the Prague Basin.

The large collections of the Middle Ordovician bivalves are deposited in the National Museum, including Barrande's and Pfab's type material. Fossiliferous nodules attracted the attention of many collectors, but particularly Klouček (1916) and Hanuš (1923) contributed markedly to the general knowledge of the Middle Ordovician fauna. In the collection of F. Hanuš (1860-1937) were found new specimens (Tatula petula gen. nov. et sp. nov., Modiolopsis sp. and Cyrtodonta sp.) from the important localities of Šárka villa and Šárka brickyard in Prague. No less important collection of the Middle Ordovician bivalves is stored in the Museum of Dr. Bohuslav Horák in Rokycany. Some of the specimens studied in this paper come from the older collection of Karel Holub and the new material were collected mainly by Jaroslav and Petr Kraft.

Middle Ordovician bivalves from the World often went through the modern revision and therefore their data are the most complex and allows us to study their relationships, distribution and biodiversification. Middle Ordovician bivalves are known from Argentina (Sánchez 1990), Australia (Pojeta \& Gilbert-Tomlinson 1977), Belgium (Maillieux 1939), China (Fang \& Cope 2004, Fang 2006, Fang \& Cope 2008), France (De Verneuil \& Barrande 1856, Barrois 1891, Babin 1966, Bradshaw 1970, Babin in 


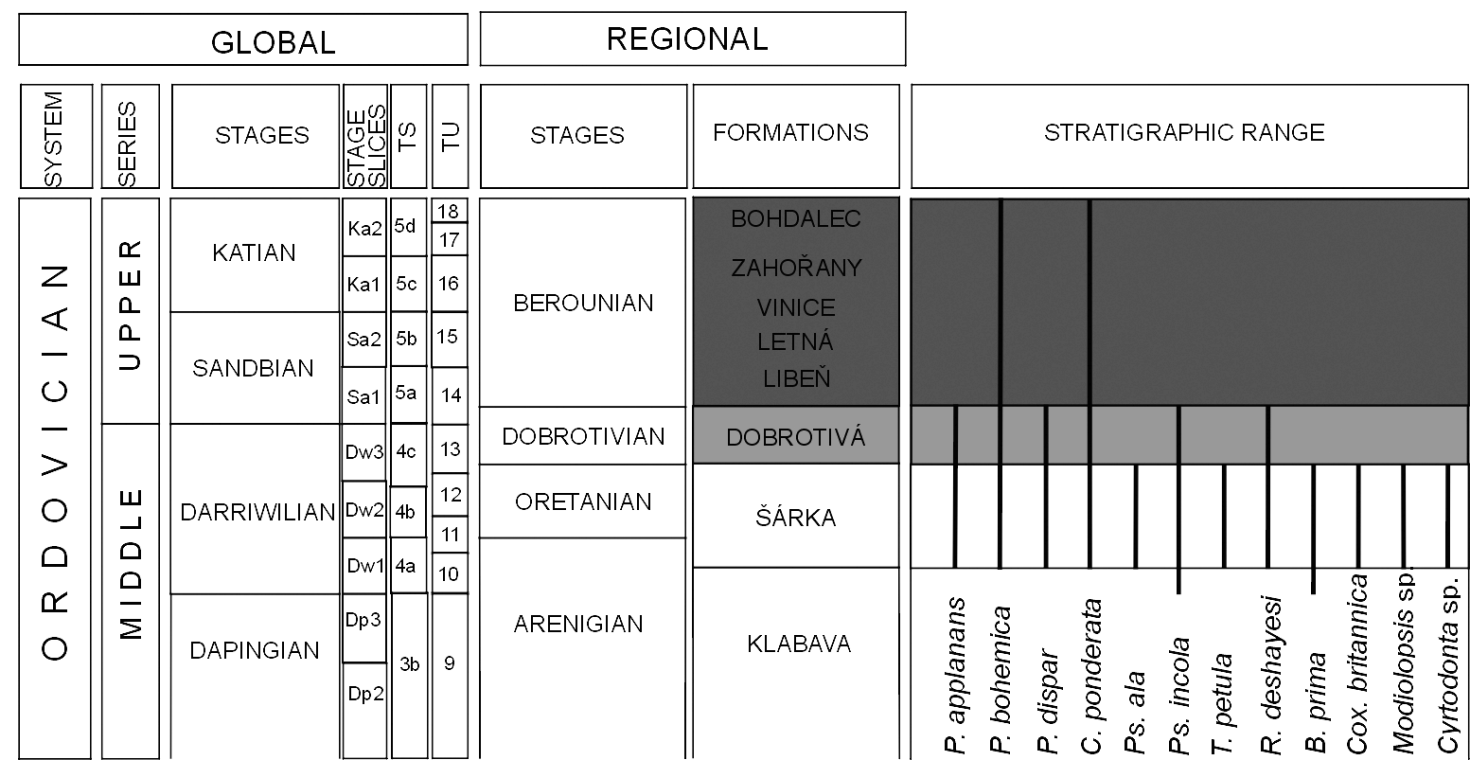

Figure 1. Global and regional stratigraphic chart for the Middle and Upper Ordovician and stratigraphic occurrence of the Middle Ordovician bivalves from Bohemia.

Babin et al. 1982, Babin \& Beaulieu 2003), Morocco (Babin \& Destombes 1990), North America (Pojeta 1971), Portugal (Delgado 1908, Sharpe 1853, Sá 2008), Spain (Sharpe 1853; De Verneuil \& Barrande 1856; Babin \& Gutiérrez-Marco 1985, 1991; Gutiérrez-Marco \& Babin 1999), Sweden (Soot-Ryen 1969) and Wales and the Welsh Borderland of England (Cope 1996, 1999).

\section{Systematic palaeontology}

Abbreviations. - V - valve; $\mathrm{L}$ - length of the shell; $\mathrm{H}$ - height of the shell; W - width of the shell; W/2 - width of one valve (Kř́ž 1969). JK, CW, PO - specimens deposited in the Czech Geological Survey, Prague; MBHR - specimens deposited in the Museum of Dr. Bohuslav Horák, Rokycany; NM - specimens deposited in the National Museum, Prague; LPB - specimens deposited in the University of Western Brittany, Brest; VPA - specimens deposited in the Complutense University, Madrid; MGM - specimens deposited in Museo Geominero, Madrid; USNM - specimens deposited in the Smithsonian Institution, Washington D.C., latex cast deposited in Czech Geological Survey, Prague. All measurements are in millimetres. The new classification used by Carter et al. (2011) is adopted here.

Class Bivalvia Linné, 1758

Subclass Protobranchia Pelseneer, 1889

Superorder Nuculiformii Gray, 1824

Order Nuculoida Dall, 1889

Superfamily Nuculoidea Gray, 1824

Family Praenuculidae McAlester, 1969

\section{Genus Praenucula Pfab, 1934}

Type species. - Praenucula dispar (Barrande, 1881), Bohemia, Prague Basin, Osek, Middle Ordovician, early and mid Darriwilian, Šárka Formation.

Discussion. - A lot of discussion was published about Praenucula and its similarity with Praeleda Pfab, 1934 and Deceptrix Fuchs, 1919 (Bradshaw 1970; Pojeta 1978; Tunnicliff 1982; Babin \& Gutiérrez-Marco 1991; Cope 1997, 1999; Babin \& Beaulieu 2003; Kříž \& Steinová 2009). McAlester (1968) decided that Deceptrix is senior synonym of Praeleda. Cope (1997) considered genus Deceptrix as valid, but probably does not occur in the Ordovician at all, but it is a genus characteristic for the Devonian. Tunnicliff (1982) described the main features of Deceptrix (in his concept synonymous with Praeleda) and Praenucula: 1) the posterior teeth in Deceptrix are smaller and more numerous than anterior teeth while in Praenucula the posterior and anterior teeth are similar in the size and number; 2) umbos in Praenucula lie in the posterior half while in Deceptrix generally lie in anterior half; 3 ) in Deceptrix the adductor muscle scars are larger and in more ventral position, in Praenucula they are close to dorsal margin. Another important but also a somewhat problematic feature was added by Cope (1999), in Praeleda between anterior and posterior hinge ranges is commonly (although not always) discordance, which is observed under the umbo. Because of this feature Cope $(1997,1999)$ grouped Praeleda into the family Cardiolariidae. But because of this problematic character, the determination of Praeleda to the family Cardiolariidae is uncertain. Cope (1997) proposed also other genus Homilodonta with crowded row of gradidentate teeth 
on the whole hinge plate. Arca subtruncata Portlock, 1843 was designated as type species. Tunnicliff (1982, pl. 9, figs 1-7, 9-11) had earlier revised this species under the name Deceptrix subtruncata. Kříž \& Steinová (2009) preferred assignation of Praeleda to the Praenuculidae and this opinion is followed here. Bradshaw (1970) was also of the opinion that hinge of Praeleda is very often similar to hinge of Praenucula and it is difficult to distinguish between these genera. Furthermore Praeleda compar, the type species of Praeleda (Zahořany Formation, Sandbian, Late Ordovician), shows the same hinge as Praenucula (there is no discordance under the umbo) and the same size of the teeth in the anterior and posterior part. Also Pfab (1934, in schema on p. 27) described the shape of the shell and shape of aductors muscle scars of both genera and showed their similarity in these features. Therefore it seems that these two genera could be congeneric. The preservation mainly in the Late Ordovician is not ideal and for the type specimens a mixture of internal, external and composite moulds was used. On the other hand Praeleda pulchra Pfab, 1934 from the Zahořany Formation shows obvious discordance between hinge ranges exactly according the definition of Cope (1999). I conclude that the revision of all Ordovician species from Bohemia, which belong to Praeleda or to Praenucula is necessary. The species from the Šárka Formation are assigned to Praenucula, but some specimens show an indication of disruption between the hinge ranges.

\section{Praenucula dispar (Barrande, 1881)}

Figures 2A-M, 5A

1881 Nucula dispar Barr.; Barrande, pl. 273, figs VII/1-8, 13-16.

1934 Praenucula dispar dispar (n. var.); Pfab, pp. 235, 236, pl. 1, fig. 3c.

1934 Praenucula dispar expansa (n. var.); Pfab, p. 235, pl. 1, fig. 3d, pl. 3, figs 10, 11, 15 a, b.

1968 Praenucula expansa Pfab. - McAlester, pp. 46, 47, pl. 8, figs 3-9.

2009 Praenucula dispar Barr. - Křǐž \& Steinová, pp. 412-414, fig. 3C, D, I, J.
Lectotype. - (SD, Pfab 1934) Internal mould of the shell with conjoined valves, figured by Barrande (1881) on pl. 273, as figs VII/1-4, NM L 27176.

Paralectotypes. - Internal moulds of the shells with conjoined valves, figured by Barrande (1881) on pl. 273, as figs VII/ 5-7 and VII/8, NM L 27177 and NM L 27178.

Type locality. - Bohemia, Prague Basin, Osek near Rokycany.

Type horizon. - Middle Ordovician, early and mid Darriwilian, Šárka Formation.

Material. - 162 specimens.

Diagnosis. - Praenucula with slightly elongated anterior part of the shell, with convexodont teeth in the posterior part, posterior adductor muscle scar placed more ventrally than anterior adductor muscle scar, three pairs of rounded accessory muscle scars in the posterior part of the umbo region.

Description. - Shell small, equivalve, inequilateral, and broadly ovate. Anterior part of the shell is larger than the posterior part. Anterior and posterior margins evenly rounded, ventral margin convex. Umbos located in the posterior half of the shell, prosogyrate. Hinge taxodont, teeth row continuous in the umbonal region (Figs 2G, H, K, 5A). Posterior part of the hinge with the convexodont teeth (the dentition comprises a varying number of teeth according to the size of the shell). In umbonal part the teeth are becoming smaller and toward the anterior slightly larger and convexodont (Fig. 11E). Anterior and posterior adductor muscle scars rounded (Fig. 2A, B, J), postero-dorsally from the anterior adductor muscle scar is a rounded pedal muscle scar (protractor) that joins the anterior adductor muscle scar (Fig. 2E, K). Dorsally from the posterior adductor muscle scar are one pair of rounded pedal muscle scars (retractor), separated from adductor muscle scar (Fig. 2J, K). Posterior adductor muscle scar placed more ventrally than anterior adductor muscle scar. Posteriorly from the umbo (but still in the umbonal region) three pairs of rounded

Figure 2. A-M - Praenucula dispar (Barrande, 1881). A - right valve, MBHR 12944, right lateral view, anterior and posterior adductor muscle scars, $\times 6.1 ; \mathrm{B}-$ articulated specimen, MBHR 14196, left lateral view, anterior and posterior adductor muscle scars, $\times 6.4$. $\bullet$ C, E - articulated specimen, MBHR 7982; C - left lateral view, $\times 6.1$; E - dorsal view, $\times 7.1$. $・$ D - right valve, MBHR 13559, right dorsolateral view, $\times 5.3 . \bullet F, H-$ articulated specimen, MBHR 14646; F - left lateral view, $\times 6.0 ; \mathrm{H}$ - dorsal view, $\times 8.2 . \cdot \mathrm{G}-$ articulated specimen, NM L 27178, dorsal view, $\times 6.9$. $\bullet$ I - left valve, MBHR 12735 , left lateral view, $\times 7.9 . \bullet \mathrm{J}, \mathrm{K}$ - articulated specimen, NM L 27176, lectotype; $\mathrm{J}-$ right lateral view with adductor and accessory muscle scars in the umbo region, $\times 10.5 ; \mathrm{K}-$ dorsal view with pedal muscle scars, $\times 16.4$. $\bullet \mathrm{L}-$ two valves, MBHR 21027, lateral view, $\times 7.3 . \bullet \mathrm{M}-$ articulated specimen, MBHR 13148, left lateral view, × 7.9. A - Prague Basin, Bohemia, Rokycany locality, early and middle Darriwilian; B - Prague Basin, Bohemia, Rokycany 17 locality, early and middle Darriwilian; C, D - Prague Basin, Bohemia, Osek 1 locality, early and middle Darriwilian; F-H - Prague Basin, Bohemia, Mýto 1 locality, early and middle Darriwilian; G, J, K - Prague Basin, Bohemia, Osek locality, early and middle Darriwilian; I - Prague Basin, Bohemia, Díly 4 locality, early and middle Darriwilian; L - Prague Basin, Bohemia, Rokycany 2 locality, early and middle Darriwilian; M - Prague Basin, Bohemia, Díly 1 locality, early and middle Darriwilian. 


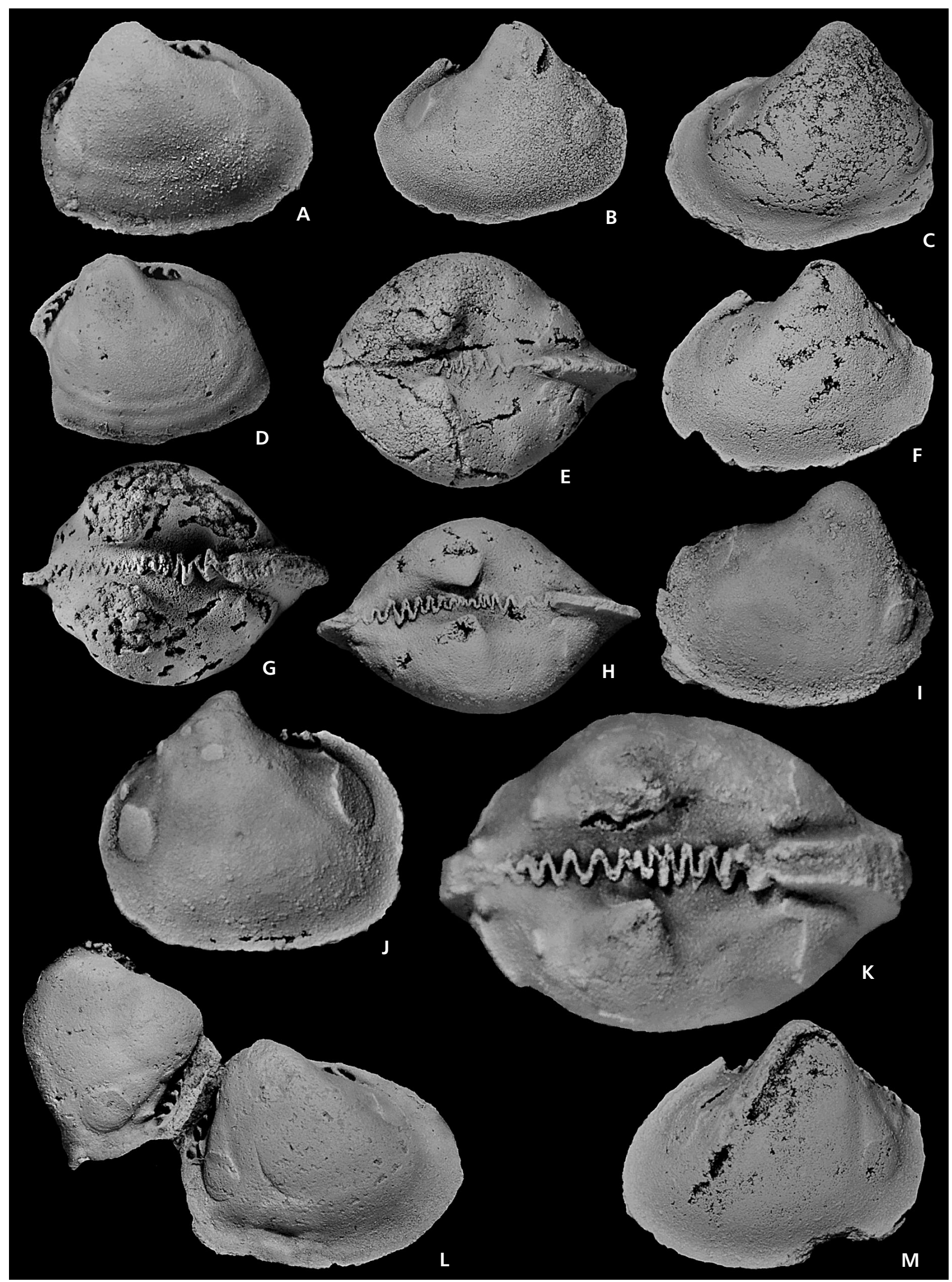


accessory muscle scars are impressed (Fig. 2J). Inner surface sculpture is smooth. The shell thickness is $0.5 \mathrm{~mm}$.

\begin{tabular}{|c|c|c|c|c|}
\hline Specimen & $\mathrm{V}$ & $\mathrm{L}$ & $\mathrm{H}$ & $\mathrm{W} / 2$ \\
\hline NM L 27176 & $\mathrm{~A}$ & 5.1 & 4.4 & 1.7 \\
\hline NM L 27177 & A & 8.5 & 3.2 & 2.5 \\
\hline MBHR 2384a & $\mathrm{A}$ & 9.6 & 7.9 & 2.6 \\
\hline MBHR 14586 & A & 8.8 & 5.9 & 2.9 \\
\hline MBHR 18914 & $\mathrm{~L}$ & 8.2 & 7.0 & 3.1 \\
\hline NM L 27178 & A & 8.1 & - & 3.1 \\
\hline MBHR 13559 & $\mathrm{R}$ & 8.0 & 5.6 & - \\
\hline MBHR 7982 & $\mathrm{~A}$ & 7.8 & 6.8 & 2.8 \\
\hline MBHR 12944 & $\mathrm{R}$ & 7.8 & 5.2 & - \\
\hline MBHR 2384b & A & 7.3 & 5.5 & 2.5 \\
\hline MBHR 21027 & $\mathrm{R}$ & 7.1 & 6.1 & - \\
\hline MBHR 2384c & A & 7.1 & 5.6 & 2.5 \\
\hline MBHR 14196 & A & 7.0 & 5.3 & 2.2 \\
\hline MBHR 14646 & A & 7.0 & 5.2 & 2.0 \\
\hline MBHR 13148 & A & 6.9 & 5.5 & 2.0 \\
\hline MBHR 12735 & A & 6.9 & 5.2 & 2.1 \\
\hline MBHR 17763 & $\mathrm{~L}$ & 6.9 & 5.0 & - \\
\hline MBHR 20564 & $\mathrm{R}$ & 6.8 & 5.1 & - \\
\hline MBHR $2384 \mathrm{~d}$ & A & 6.6 & 5.1 & 1.9 \\
\hline MBHR 13579 & $\mathrm{R}$ & 6.5 & 5.1 & - \\
\hline MBHR 13447 & $\mathrm{~A}$ & 6.5 & 5.0 & - \\
\hline MBHR 15294b & A & 6.1 & 5.1 & 2.2 \\
\hline MBHR 9041 & A & 6.1 & 5.1 & 2.0 \\
\hline MBHR 13121 & $\mathrm{~L}$ & 6.1 & 5.1 & - \\
\hline MBHR 2384d & $\mathrm{A}$ & 6.1 & 5.0 & 1.8 \\
\hline MBHR 20348 & A & 6.1 & 4.9 & 1.9 \\
\hline MBHR 20385 & A & 6.1 & 4.8 & 1.5 \\
\hline MBHR 20365 & A & 6.1 & 4.1 & 1.7 \\
\hline MBHR 20349 & A & 6.0 & 5.1 & 2.0 \\
\hline MBHR 14664 & $\mathrm{R}$ & 6.0 & 4.7 & - \\
\hline MBHR 20364 & $\mathrm{~A}$ & 6.0 & 4.5 & 1.7 \\
\hline MBHR 20366 & A & 5.9 & 5.0 & 1.9 \\
\hline MBHR 2384f & A & 5.8 & 4.9 & 1.5 \\
\hline MBHR 20386 & A & 5.5 & 4.8 & 1.7 \\
\hline MBHR 17776a & $\mathrm{R}$ & 5.5 & 3.9 & - \\
\hline MBHR 2384g & A & 5.5 & 4.1 & 1.7 \\
\hline MBHR 15294a & A & 5.2 & 4.0 & 1.5 \\
\hline MBHR 20341 & A & 5.1 & 4.0 & 1.0 \\
\hline MBHR 13143 & $\mathrm{R}$ & 5.0 & 4.0 & - \\
\hline MBHR 2384h & A & 5.0 & 3.8 & 1.5 \\
\hline MBHR 20387 & A & 4.9 & 3.9 & 1.5 \\
\hline MBHR 14694 & $\mathrm{R}$ & 4.9 & - & 0.9 \\
\hline MBHR 19154 & $\mathrm{R}$ & 4.8 & 3.9 & - \\
\hline MBHR 17798 & A & 4.8 & 3.8 & 1.5 \\
\hline MBHR 14204 & $\mathrm{R}$ & 4.7 & 3.9 & - \\
\hline MBHR 4624 & $\mathrm{~L}$ & 4.5 & 3.8 & - \\
\hline MBHR 24050 & A & 4.5 & 3.1 & 0.8 \\
\hline MBHR 14360 & $\mathrm{R}$ & 4.1 & 3.5 & 1.9 \\
\hline MBHR 18846 & $\mathrm{R}$ & 4.1 & 2.9 & - \\
\hline
\end{tabular}

$\begin{array}{llllr}\text { MBHR 2384i } & \text { A } & 4.0 & 3.1 & 1.0 \\ \text { MBHR 20347 } & \text { A } & 4.0 & 3.0 & 1.2 \\ \text { MBHR 15277 } & \mathrm{L} & 4.0 & 3.0 & - \\ \text { MBHR 13145 } & \mathrm{R} & 4.0 & 2.9 & - \\ \text { MBHR 14847 } & \mathrm{R} & 3.8 & 2.9 & - \\ \text { MBHR 55903 } & \mathrm{L} & 3.8 & - & - \\ \text { MBHR 20391 } & \mathrm{A} & 3.6 & 2.9 & 1.0 \\ \text { MBHR 19481 } & \mathrm{R} & 3.6 & 2.5 & - \\ \text { MBHR 14298 } & \mathrm{L} & 3.5 & 2.9 & - \\ \text { MBHR 14297 } & \mathrm{R} & 3.5 & 2.9 & - \\ \text { MBHR 14842 } & \mathrm{R} & 3.5 & 2.5 & - \\ \text { MBHR 20364 } & \mathrm{A} & 3.4 & 2.0 & 0.7 \\ \text { MBHR 18784b } & \mathrm{R} & 3.3 & 2.9 & - \\ \text { MBHR 20388 } & \mathrm{A} & 3.2 & 2.0 & 0.7 \\ \text { MBHR 18784a } & \mathrm{L} & 3.1 & 2.8 & - \\ \text { MBHR 1776 } & \mathrm{L} & 3.1 & 2.0 & - \\ \text { MBHR 2420 } & \mathrm{R} & 2.9 & 2.8 & - \\ \text { MBHR 14368 } & \mathrm{A} & 2.9 & 2.0 & - \\ \text { MBHR 20351 } & \mathrm{A} & 2.8 & 2.0 & 0.9 \\ \text { MBHR 19495 } & \mathrm{A} & 2.6 & 2.0 & - \\ \text { MBHR 20389 } & \mathrm{A} & 2.0 & 1.3 & 0.6\end{array}$

Discussion. - P. dispar differs from P. bohemica in convexodont teeth in the posterior part and in position of posterior adductor muscle scar, which is in $P$. bohemica close to the dorsal margin of the shell. $P$. dispar differs from $P$. applanans in the shape of the shell, in the more posterior position of the umbo, in convexodont teeth in the posterior part and in the position of the posterior adductor muscle scar, which is in $P$. applanans close to the dorsal margin. The comparison with the other species of Praenucula is in Kř̌̌ž \& Steinová (2009).

Occurrence. - Bohemia, Prague Basin, early and mid Darriwilian: Díly, Drahouš, Malé Přílepy, Mýto, Osek, Rokycany, Šárka brickyard, Šárka field, Těškov.

Praenucula bohemica (Barrande, 1881) Figures 3A-S, 5B

1881 Leda bohemica Barr.; Barrande, pl. 269, figs I/1-4, $\mathrm{VII} / 1,2$.

1934 Ctenodonta bohemica Barr. - Pfab, p. 223, pl. 2 (3), figs 4-6.

Lectotype. - (SD, Pfab 1934) Internal mould of the shell with conjoined valves, figured by Barrande (1881) on pl. 269, as figs I/1-4, NM L 27114.

Type locality. - Bohemia, Prague Basin, Osek near Rokycany.

Type horizon. - Middle Ordovician, early and mid Darriwilian, Šárka Formation. 
Material. - 182 specimens.

Diagnosis. - Praenucula with almost orthomorphodont or slightly concavodont teeth in posterior part, with ovate anterior adductor muscle scar placed more ventrally than posterior adductor muscle scar and with straight posterior margin.

Description. - Shell small, equivalve, inequilateral, and broadly ovate. Anterior margin is longitudinally elongated and posterior margin is straight, ventral margin slightly convex. Posterior part of the shell is shorter than anterior part. Umbos located in the posterior half of the shell, close to the middle of the shell, prosogyrate. Hinge taxodont, teeth row continuous in the umbonal region (Figs 3B, C, M, 5B). Posterior part of the hinge with almost orthomorphodont teeth, or slightly concavodont (Fig. 3E, F). Anterior part of the hinge with convexodont teeth (Fig. 3S). Posterior adductor muscle scar slightly elliptic, smaller than anterior adductor muscle scar (Fig. 3L). Anterior adductor muscle scar is ovate, posterior part of the anterior muscle scar is prominently narrower (Fig. 3L, M). Anterior adductor muscle scar placed more ventrally than posterior adductor muscle scar. Antero-dorsally from the posterior adductor muscle scars is separated pedal muscle scar (retractor) (Fig. 3M). Anterior pedal muscle scar joined with anterior adductor muscle scar (Fig. 3M). Inner surface sculpture is smooth.

$\begin{array}{llrrr}\text { Dimensions. }- & & & & \\ \text { Specimen } & \text { V } & \text { L } & \text { H } & \text { W/2 } \\ \text { MBHR 2377 } & \text { L } & 11.8 & 9.0 & 2.5 \\ \text { MBHR 2443 } & \text { A } & 11.1 & 6.9 & - \\ \text { MBHR 2380 } & \text { A } & 10.1 & 7.9 & 3.0 \\ \text { LPB 562 (France) } & \text { L } & 10.0 & 8.1 & - \\ \text { MBHR 14765 } & \text { L } & 9.8 & 7.1 & - \\ \text { CW 1 } & \text { R } & 9.7 & 8.7 & 2.5 \\ \text { MBHR 12584 } & \text { L } & 9.5 & 7.2 & - \\ \text { MBHR 7911 } & \text { L } & 9.0 & 6.6 & 2.2 \\ \text { MBHR 20457 } & \text { A } & 8.9 & 7.0 & 2.8 \\ \text { MBHR 14694 } & \text { L } & 8.5 & 7.0 & - \\ \text { MBHR 14768 } & \text { A } & 8.2 & 6.0 & 2.2 \\ \text { MBHR 14841 } & \text { L } & 8.0 & 5.9 & - \\ \text { MBHR 4724 } & \text { R } & 8.0 & 5.5 & 1.5 \\ \text { MBHR 14692 } & \text { R } & 7.5 & 5.5 & - \\ \text { NM L 27114 } & \text { A } & 7.2 & 6.2 & 2.3 \\ \text { MBHR 20346 } & \text { A } & 7.1 & 6.0 & 2.0 \\ \text { MBHR 14467 } & \text { A } & 7.1 & 5.1 & 2.0 \\ \text { MBHR 7580a } & \text { A } & 6.8 & 5.0 & 1.7 \\ \text { MBHR 12417 } & \text { A } & 6.6 & - & 2.0 \\ \text { MBHR 7580b } & \text { A } & 6.0 & 5.0 & 1.8 \\ \text { MBHR 14448 } & \text { A } & 5.9 & 4.5 & 1.7 \\ \text { MBHR 20458 } & \text { A } & 5.8 & 4.0 & 1.7 \\ \text { MBHR 20390 } & \text { A } & 5.8 & 3.5 & 1.7 \\ \text { MBHR 7580c } & \text { A } & 5.2 & 3.8 & 1.8\end{array}$

$\begin{array}{lllll}\text { MBHR 7580d } & \text { A } & 4.1 & 3.4 & 1.1 \\ \text { MBHR 2384j } & \text { A } & 3.3 & 3.0 & 0.9\end{array}$

Discussion. - Pfab (1934) mentioned that Praeleda compar (originally described from the Zahořany Formation, Sandbian) occurs also in the Śáka Formation. Because Praeleda compar and Praenucula bohemica are very similar, it is very difficult to recognise them well, but in my opinion Praeleda compar does not occur in the Šárka Formation. $P$. bohemica is very similar, if not conspecific with P. costae (Fig. 30-Q) from the Middle Ordovician of France, Portugal and Spain. Nevertheless for now it is preferred to keep these two species, because $P$. costae always shows the pedal muscle scar half way along the posterior hinge plate, which is not preserved in P. bohemica. P. costae possesses convexo-concave and concave teeth in the posterior part of the hinge, in $P$. bohemica they are rather orthomorphodont. This Praenucula-like morphology" was really frequent in the Middle and Late Ordovician bivalves. $P$. bohemica differs from $P$. dispar in the hinge $(P$. bohemica has in the posterior part almost orthomorphodont or slightly concavodont teeth) and in the position of adductor muscle scars (in P. dispar the posterior adductor muscle scar is placed more ventrally than the anterior adductor muscle scar). P. applanans differs from $P$. bohemica in the more centrally placed umbo and in larger posterior part of the shell. The shell of $P$. applanans is generally larger. The shorter form of $P$. mayennense Babin \& Beaulieu, 2003 from the Middle Ordovician of the Armorican Massif, France seems to be very similar with $P$. bohemica, it differs mainly in the more rounded anterior part of the shell and stronger anterior teeth. P. dispersa Tunnicliff, 1982 from the Bardahessiagh Formation, Late Ordovician of Ireland has convexodont teeth in the posterior part and smaller rounded adductor muscle scars. $P$. infirma Tunnicliff, 1982 from the Killey Bridge Formation, Late Ordovician of Ireland shows rounded anterior part of the shell, convexodont teeth in the posterior part and the smaller rounded adductor muscle scars. $P$. praetermissa Tunnicliff, 1982 from the Killey Bridge Formation, Late Ordovician of Ireland has convexodont teeth in posterior part and umbo in more central position.

Occurrence. - Bohemia, Prague Basin, Darriwilian: Čtyřdomky, Díly, Drahouš, Mýto, Osek, Rokycany, Śárka field, Úvaly, Malé Přílepy, Kařizek, Sandbian: Drabov, Trubín, Trubsko, Katian: Prague-Strašnice, Prague-Michle, Loděnice.

\section{Praenucula applanans (Barrande, 1881)}

Figures 4A-R, 5C

1881 Nucula applanans Barr. - Barrande, pl. 272, figs III/1-12. 
1934 Ctenodonta applanans Barr. - Pfab, p. 222, pl. 2 (3), figs $1-3$.

1991 Praenucula sharpei Babin \& Gutiérrez-Marco; Babin \& Gutiérrez-Marco, pp. 115, 116, pl. 2, figs 1-6.

Lectotype. - (SD, Pfab 1934.) Internal mould of the shell with conjoined valves, figured by Barrande (1881) on pl. 272, as figs III/5-8, NM L 27163.

Paralectotypes. - Internal moulds of the shells with conjoined valves, figured by Barrande (1881) on pl. 272, as figs III/ 1-4 and III/9-12, NM L 27161 and NM L 27162.

Type locality. - Bohemia, Prague Basin, Osek near Rokycany.

Type horizon. - Middle Ordovician, early and mid Darriwilian, Šárka Formation.

Material. - 172 specimens.

Diagnosis. - Praenucula with slightly larger posterior part of the shell, umbo almost in the middle of the shell, slightly prosogyrate, orthomorphodont teeth in the posterior part.

Description. - Shell small, equivalve, slightly inequilateral, and broadly ovate. Posterior part of the shell is slightly larger than the anterior part. Anterior part is elongated, posterior part rounded. Ventral margin convex. The umbos located slightly in the posterior part, more often in the middle of the shell, slightly prosogyrate. Hinge taxodont, continuous in the umbonal region (Figs 4B, K, 5C). Convexodont teeth in the anterior part slightly larger, posterior teeth orthomorphodont or slightly concavodont (Fig. 4B, K, P). Anterior adductor muscle scar is elliptic, posterior part of the anterior adductor muscle scar narrower. Anterior pedal muscle scar is joined with adductor muscle scar (Fig. 4B, K). Posterior adductor muscle scar slightly elongated, one posterior pedal muscle scar is developed antero-dorsally from the posterior adductor muscle scar (Fig. 4K). Three pairs of rounded accessory muscle scars in the umbo region (Fig. 3K). Inner surface sculpture is smooth.
Dimensions. -

$\begin{array}{llrrr}\text { Specimen } & \mathrm{V} & \mathrm{L} & \mathrm{H} & \mathrm{W} / 2 \\ \text { VPA 2144/OR (Spain) } & \mathrm{A} & 14.8 & 11.0 & - \\ \text { MBHR 2350 } & \mathrm{R} & 13.9 & 8.0 & - \\ \text { MBHR 4624 } & \mathrm{R} & 12.2 & 7.9 & 2.5 \\ \text { MBHR 14852 } & \mathrm{A} & 11.5 & 7.6 & 2.5 \\ \text { NM L27163 } & \mathrm{A} & 11.0 & 6.9 & 2.1 \\ \text { MBHR 2384k } & \mathrm{A} & 7.1 & 10.7 & 2.5 \\ \text { MBHR 15529 } & \mathrm{R} & 10.5 & 7.1 & - \\ \text { MBHR 14233 } & \mathrm{L} & 10.1 & 7.5 & 1.9 \\ \text { MBHR 2381 } & \mathrm{A} & 10.1 & 7.5 & 1.5 \\ \text { MBHR 2395 } & \mathrm{A} & 10.0 & 8.0 & 3.0 \\ \text { MBHR 2373 } & \mathrm{L} & 10.0 & 7.5 & 2.0 \\ \text { MBHR 23841 } & \mathrm{A} & 10.0 & 6.8 & 2.4 \\ \text { MBHR 14663 } & \mathrm{L} & 10.0 & 6.8 & - \\ \text { MBHR 18858 } & \mathrm{A} & 10.0 & - & 2.0 \\ \text { MBHR 12570 } & \mathrm{L} & 9.8 & 6.5 & - \\ \text { MBHR 7585 } & \mathrm{A} & 9.5 & 7.0 & 4.9 \\ \text { MBHR 14619 } & \mathrm{A} & 9.4 & 6.6 & 2.5 \\ \text { MBHR 20406 } & \mathrm{A} & 9.3 & 5.5 & 3.8 \\ \text { MBHR 2395b } & \mathrm{L} & 9.2 & 6.5 & 3.2 \\ \text { MBHR 4591 } & \mathrm{R} & 9.2 & 6.5 & 2.5 \\ \text { NM L27161 } & \mathrm{L} & 9.1 & 6.5 & - \\ \text { MBHR 50268 } & \mathrm{R} & 9.0 & 7.1 & - \\ \text { MBHR 21066 } & \mathrm{R} & 9.0 & 6.8 & - \\ \text { MBHR 15289 } & \mathrm{L} & 8.9 & - & - \\ \text { MBHR 24030 } & \mathrm{A} & 8.8 & 6.0 & 2.1 \\ \text { NM L27162 } & \mathrm{A} & 8.6 & 6.0 & 1.8 \\ \text { MBHR 14843 } & \mathrm{A} & 8.1 & 5.5 & - \\ \text { MBHR 20383 } & \mathrm{A} & 8.0 & 5.8 & 1.8 \\ \text { MBHR 2384m } & \mathrm{A} & 8.0 & 5.4 & 1.5 \\ \text { MBHR 14607 } & \mathrm{A} & 7.9 & 6.0 & 2.0 \\ \text { MBHR 21040 } & \mathrm{A} & 7.9 & 5.1 & 1.7 \\ \text { MBHR 19027 } & \mathrm{A} & 7.2 & 4.3 & 1.0 \\ \text { MBHR 2384n } & \mathrm{A} & 7.2 & 4.5 & 1.9 \\ \text { MBHR 13453 } & \mathrm{L} & 7.1 & 5.5 & - \\ \text { MBHR 4600 } & \mathrm{R} & 7.0 & 6.0 & 2.3 \\ \text { MBHR 13370 } & \mathrm{R} & 6.9 & 4.9 & - \\ \text { MBHR 2384o } & \mathrm{A} & 6.5 & 5.0 & 1.4 \\ \text { MBHR 20451 } & \mathrm{R} & 6.5 & 5.0 & - \\ \text { M } & & 6.2 & 4.9 & - \\ \text { MBH1 } & & & 4.5 & 1.2 \\ \text { MB1 } & & & \end{array}$

Figure 3. A-N, R, S - Praenucula bohemica (Barrande, 1881). A, B - articulated specimen, MBHR 14448; A - right lateral view, $\times 6.6$; B - dorsal view, $\times$ 6.4. $\bullet$ C, D - articulated specimen, MBHR 20390; C - dorsal view, $\times 7.2$; D - left lateral view with adductor muscle scars, $\times 6.5$. E, F - articulated specimen, $\mathrm{CW} 1$; E - right lateral view, $\times 3.8 ; \mathrm{F}-$ right dorsolateral view with orthomorphodont dentition in the posterior part, $\times 4.3$. $\bullet \mathrm{G}, \mathrm{H}-$ articulated specimen, MBHR 7580c; G - dorsal view, $\times 8.6 ; \mathrm{H}-$ left lateral view, $\times 6.3$. $\bullet \mathrm{I}-\mathrm{K}-$ articulated specimen, NM L 27114 , lectotype; I - right lateral view, $\times 6.5 ; \mathrm{J}-$ dorsal view, $\times 9.0 ; \mathrm{K}-$ left lateral view, $\times 6.1 . \bullet \mathrm{L}-\mathrm{N}-$ articulated specimen, MBHR 20457; $\mathrm{L}-$ left lateral view with adductor muscle scars, $\times 4.8 ; \mathrm{M}-$ dorsal view with pedal muscle scars, $\times 8.8 ; \mathrm{N}$ - detail of pedal muscle scars in the posterior part (retractors), $\times 9.2$. $\bullet$ R, $\mathrm{S}-$ left valve, MBHR 2377; R - left lateral view, $\times 4.5$; S - left dorsolateral view, $\times 6.1$ • O-Q - Praenucula costae (Sharpe, 1853); O, P - right valve, MGM642-O; O - right lateral view, $\times 2.4$; P - dorsal view, $\times 3.3$; Q - left valve, LPB 562, left dorsolateral view, $\times 4.9$. A, B - Prague Basin, Bohemia, Díly 1 locality, early and middle Darriwilian; C, D - Prague Basin, Bohemia, Díly 3 locality, early and middle Darriwilian; E-H - Prague Basin, Bohemia, Osek 1 locality, early and middle Darriwilian; I-K - Prague Basin, Bohemia, Osek locality, early and middle Darriwilian; L, N, R, S - Prague Basin, Bohemia, Rokycany locality, early and middle Darriwilian; O, P - Spain, Calzada-Viso del Marques locality, Darriwilian; Q - France, Morgat locality, late Darriwilian. 


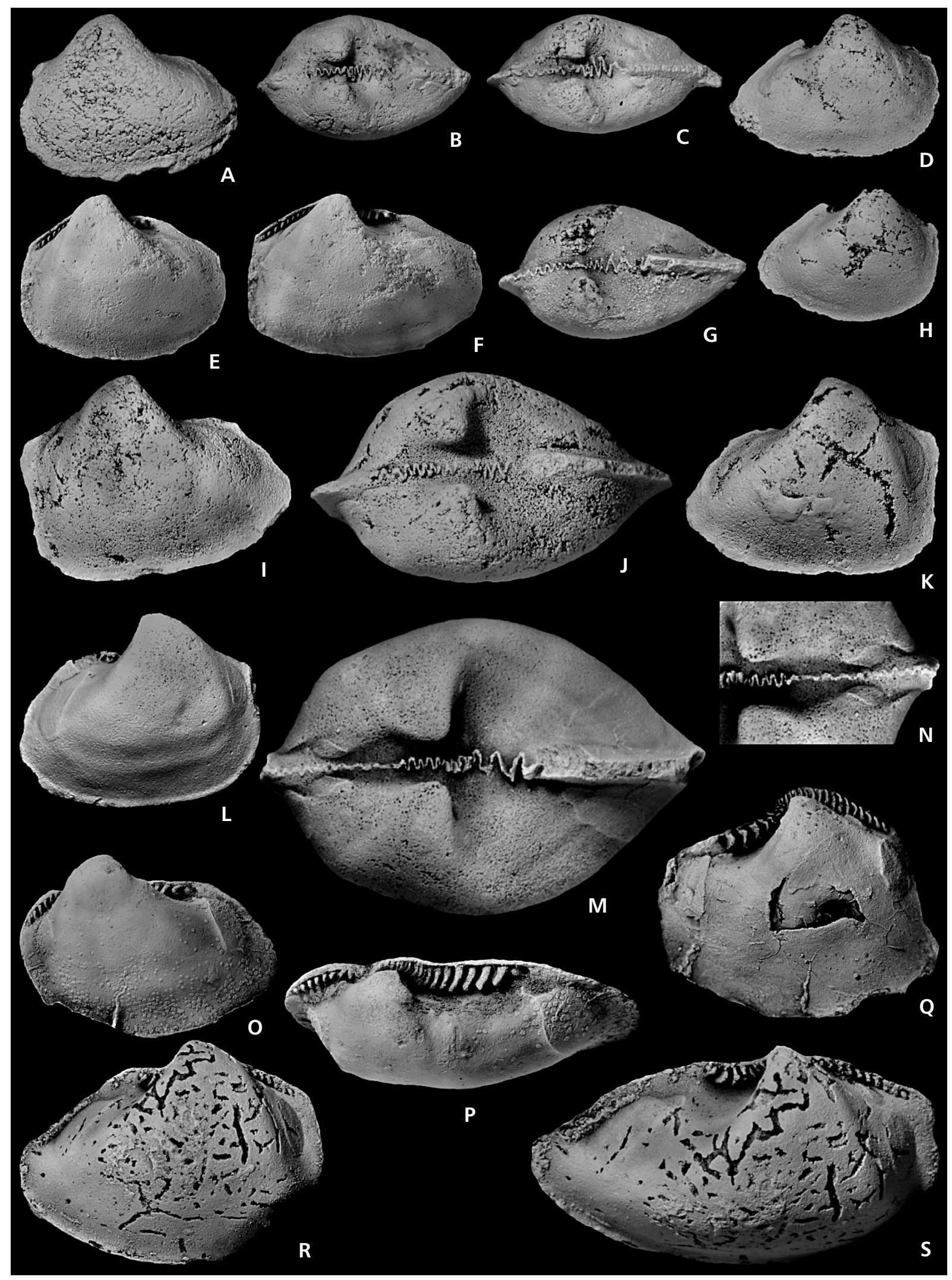




$\begin{array}{llllr}\text { MBHR 17771 } & \text { A } & 6.0 & 4.5 & 2.6 \\ \text { MBHR 17996 } & \text { R } & 5.9 & 4.5 & - \\ \text { MBHR 20372 } & \text { A } & 5.1 & 4.0 & 1.0\end{array}$

Discussion. - P. applanans differs from $P$. dispar in the larger posterior part of the shell, its umbo in the central position, concavodont teeth in the anterior part of the shell and in the elliptical adductor musle scar. $P$. applanans differs from $P$. bohemica in the larger posterior part of the shell and in the umbo in central position. The shorter form of Praenucula mayennense Babin \& Beaulieu, 2003 from the Middle Ordovician of the Armorican Massif, France differs in its more posteriorly placed umbo and stronger and larger anterior teeth. P. dispersa Tunnicliff, 1982 from the Bardahessiagh Formation, Late Ordovician of Ireland shows convexodont teeth in the posterior part and smaller, rounded adductor muscle scars. $P$. infirma Tunnicliff, 1982 from the Killey Bridge Formation, Late Ordovician of Ireland differs in the rounded anterior part of the shell, convexodont teeth in the posterior part and smaller, rounded adductor muscle scars. P. praetermissa Tunnicliff, 1982 from the Killey Bridge Formation, Late Ordovician of Ireland has convexodont teeth in the posterior part.

Occurrence. - Bohemia, Prague Basin, Darriwilian: Díly, Drahouš, Cheznovice, Osek, Malé Přílepy, Pětidomky, Rokycany, Šárka field; Spain, Hesperian Massif, Darriwilian: Alia Navalpino, Navas de Estena-Retuerta, Ventas.

\section{Genus Concavodonta Babin \& Melou, 1972}

Type species. - Concavodonta ponderata (Barrande, 1881), Bohemia, Prague Basin, Middle and Late Ordovician, Darriwilian, Sandbian, Katian, Šárka, Dobrotivá, Libeň, Letná, Vinice, Zahořany and Bohdalec formations.

\section{Concavodonta ponderata (Barrande, 1881)}

Figure $7 \mathrm{~A}-\mathrm{F}$

1881 Nucula ponderata Barr.; Barrande, pl. 271, figs IV/1-4.
1934 Ctenodonta ponderata Barr. - Pfab, p. 224, pl. 2, fig. 7.

1972 Concavodonta ponderata Barr. - Babin \& Melou, pl. 7, figs 5-7.

1973 Ctenodonta? ponderata Barr. - Babin \& Robardet, pl. 1, figs $1-6$.

Holotype. - Internal mould of the shell with conjoined valves, figured by Barrande on pl. 271 as figs IV/1-4, NM L 22682.

Type locality. - Bohemia, Prague Basin, Loděnice.

Type horizon. - Late Ordovician, early Katian, Zahořany Formation.

Material. - Two left valves, two right valves, one articulated specimen.

Diagnosis. - Concavodonta characterized by rounded outline, with rounded adductor muscle scars; anterior and posterior dorsal borders meet at an angle of $100^{\circ}$.

Description. - Shell small, equivalve, slightly inequilateral, and rounded. Anterior part of the shell is slightly smaller than the posterior part. Anterior and posterior dorsal borders meet at an angle of $100^{\circ}$. Ventral margin convex. The umbos located in the middle of the shell or very slightly in the anterior part, slightly prosogyrate. Hinge taxodont, continuous in the umbonal region. Concavodont teeth in the posterior, the most posterior teeth orthomorphodont, diconvexodont teeth in the anterior part slightly larger; under the umbo small orthomorphodont teeth (Fig. 7D, E). Anterior and posterior teeth increasing in size gradually from umbo towards distal hinge margins, but the most anterior and the most posterior teeth are again smaller. Anterior adductor muscle scar rounded, more deeply impressed than rounded posterior addductor muscle scar (Fig. 7D). Inner surface sculpture is smooth. Outer surface sculpture with commarginal rough lines (preserved in Late Ordovician Concavodonta ponderata from France, Babin \& Melou 1972, pl. VI, fig. 7).

Figure 4. A-R - Praenucula applanans (Barrande, 1881). A-C - articulated specimen, NM L 27161, paralectotype; A - right lateral view with anterior adductor muscle scar, $\times 4.0 ; \mathrm{B}-$ dorsal view, $\times 6.4 ; \mathrm{C}-$ left lateral view, $\times 4.1 . \cdot \mathrm{D}-$ articulated specimen, MBHR 14852 , right lateral view, $\times 3.3$. - E, F - left valve, MBHR 12570, E - left dorsolateral view, $\times 6.5$; F - left lateral view, $\times 4.2$. $・$ G, H, O - articulated specimen, NM L 27162, paralectotype; $\mathrm{G}$ - right lateral view, $\times 4.4 ; \mathrm{H}-$ dorsal view, $\times 7.3 ; \mathrm{O}-$ left lateral view, $\times 4.0 . \cdot \mathrm{I}-$ articulated specimen, VPA $2144 / \mathrm{OR}$, right dorsolateral view, $\times 2.9$. $\bullet \mathrm{J}, \mathrm{K}-$ articulated specimen, MBHR $14619 ; \mathrm{J}$ - right lateral view, $\times 3.5 ; \mathrm{K}-$ dorsal view with hinge and adductor and accessory muscle scars, $\times 6.1 \cdot \bullet \mathrm{L}-\mathrm{N}-$ articulated specimen, $\mathrm{NM} \mathrm{L} 27163$, lectotype; $\mathrm{L}-$ left lateral view, $\times 3.9 ; \mathrm{M}-$ right lateral view, $\times 3.7 ; \mathrm{N}-$ dorsal view, $\times 3$. $\bullet \mathrm{P}-$ articulated specimen, opened shell, MBHR 2395, right lateral view with orthomorphodont teeth in the posterior part, $\times 5.3$. $\bullet$ Q - right valve, MBHR 4600, dorsal view, × 9.5. $\bullet$ R - articulated specimen, opened shell, MBHR 2443, left lateral view, × 3.8. A-C, G, H, O, L, M, Q-Prague Basin, Bohemia, Osek locality, early and middle Darriwilian; D, J, K, N - Prague Basin, Bohemia, Osek 1 locality, early and middle Darriwilian; E, F - Prague Basin, Bohemia, Rokycany 2 locality, early and middle Darriwilian; I - Spain, Ventas, early Darriwilian; P - Prague Basin, Bohemia, Rokycany locality, early and middle Darriwilian; R - Prague Basin, Bohemia, Drahouš 1 locality, early and middle Darriwilian. 


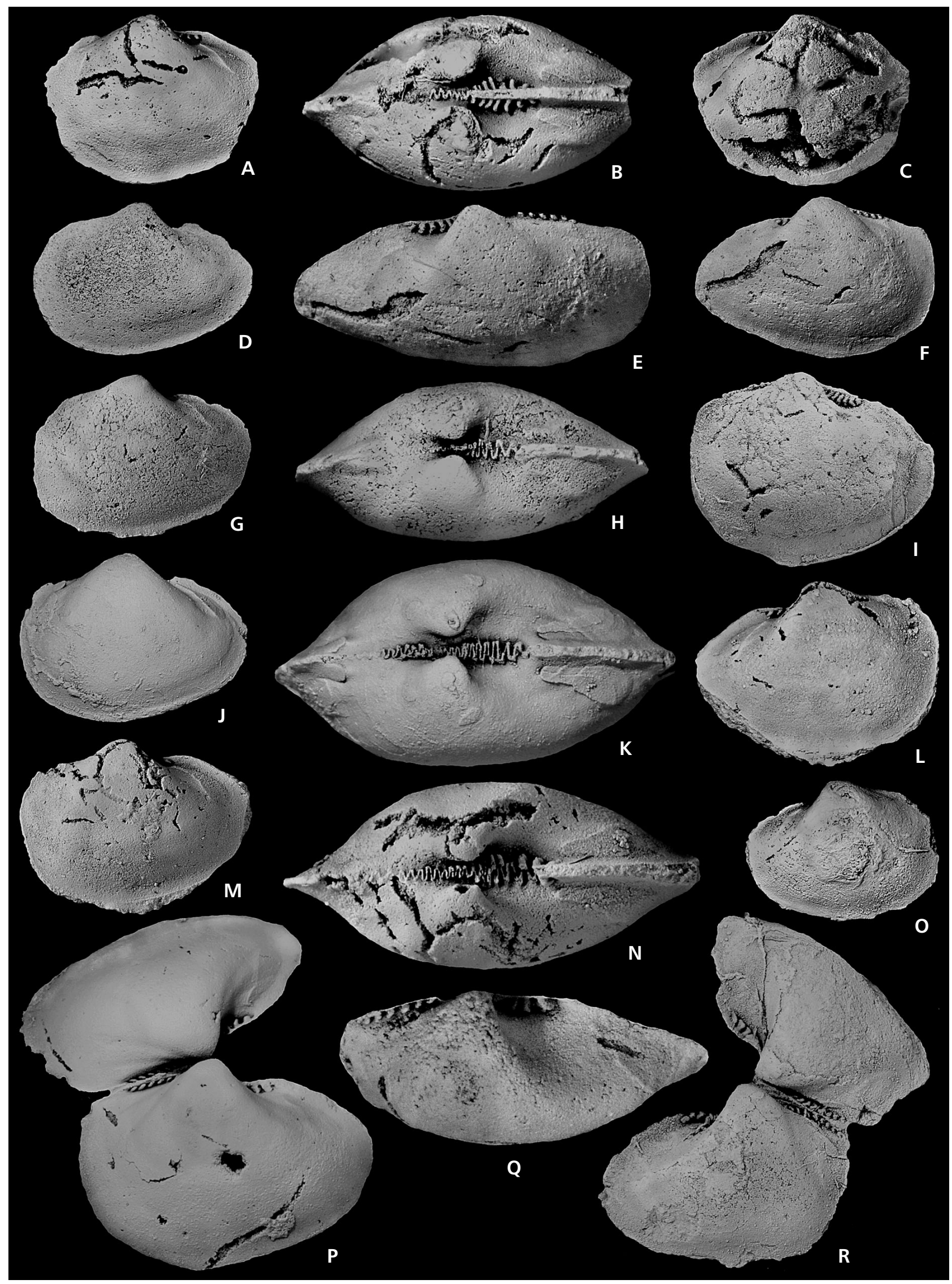



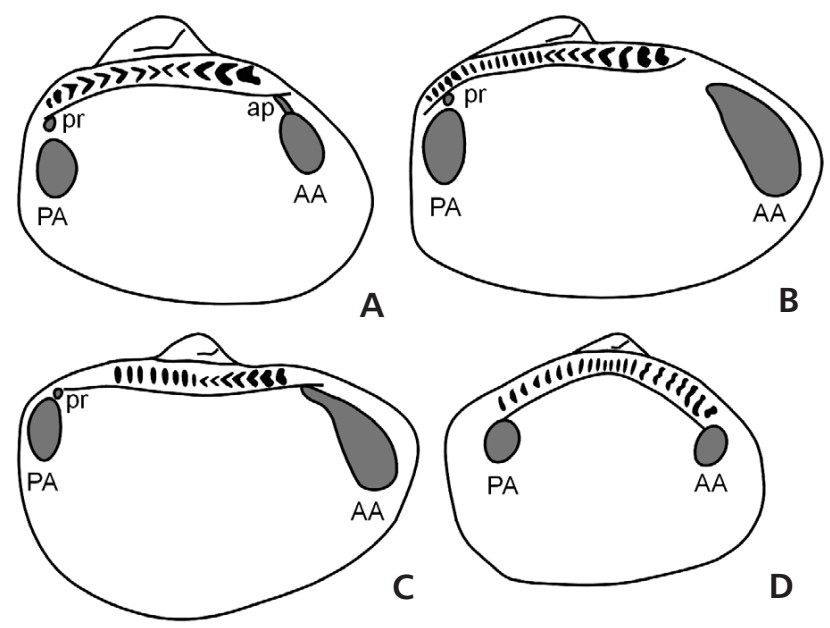

B

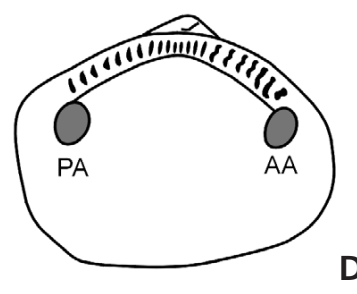

Figure 5. A - Praenucula dispar (Barrande, 1881), left lateral view showing hinge and muscle scars. • B - Praenucula bohemica (Barrande, 1881), left lateral view showing hinge and muscle scars. $\bullet \mathrm{C}-$ Praenucula applanans (Barrande, 1881), left lateral view showing hinge and muscle scars. • D - Concavodonta ponderata (Barrande, 1881), left lateral view showing hinge and muscle scars. Key to letter symbols: AA - anterior adductor muscle scar; PA - posterior adductor muscle scar; ap - anterior protractor muscle scar; $\mathrm{pr}$ - posterior retractor muscle scar.

\section{Dimensions. -}

Specimen

NM L 42215

NM L 42216

NM L 42217

$\begin{array}{lr}\text { V } & \text { L } \\ \text { L } & 7.1 \\ \text { L } & 7.9 \\ \text { A } & 5.7\end{array}$

L
7.1
7.9
5.7

$\mathrm{H}$
5.5
6.8
5.6

$\mathrm{W} / 2$

Discussion. - Barrande (1881) described Concavodonta ponderata from the Zahořany Formation (Katian, Late Ordovician) and Pfab (1934) found this species also in the Śarka Formation and assigned it to Ctenodonta. He noticed that the hinge is somewhat different. Babin \& Melou (1972) designated Ctenodonta ponderata as the type species of their new genus Concavodonta. Sánchez (1999) included $C$. ponderata to the new subfamily Concavodontinae with the diagnosis: posterior teeth in chevron with concavities towards umbo (concavodont dentition); in anterior hinge, dentition is concavodont or convexodont. C. ponderata from Bohemia shows in the anterior part diconvexodont teeth, which is different from the diagnosis of Concavodontinae (see below functional mophology in the Ordovician Protobranchia). C. ovalis Sánchez, 1999 from the Don Braulio Formation, Late Ordovician of Argentina differs from $C$. ponderata in its ovate outline and the ovate anterior adductor muscle scar. The shell borders meet with angle of $150^{\circ}$ in $C$. ovalis and $100^{\circ}$ in C. ponderata. C. imbricata (Portlock, 1843) from the Killey Bridge Formation, Late Ordovician of Ireland shows more ovate shell outline.

Occurrence. - Bohemia, Prague Basin, early and mid Darriwilian: Osek, Šárka field, Prague-Vokovice, Sandbian: Trubsko, Trubín, Vinice, Katian: Loděnice, PragueStrašnice.

Infraclass Heteroconchia Hertwig, 1895

Cohort Cardiomorphi Férussac, 1822 (in Férussac \&

Audebard 1822) (= Heterodonta)

Order Actinodontida Dechaseaux, 1952

Superfamily Anodontopsoidea Miller, 1889

Family Cycloconchidae Ulrich, 1894 (in Ulrich \&

Scofield 1894)

Subfamily Cycloconchinae Ulrich, 1894 (in Ulrich \&

Scofield 1894)

\section{Genus Pseudocyrtodonta Pfab, 1934}

Type species. - Pseudocyrtodonta ala (Barrande, 1881), Bohemia, Prague Basin, Osek, Middle Ordovician, early and middle Darriwilian, Šárka Formation.

\section{Pseudocyrtodonta ala (Barrande, 1881)}

Figure 6A-C

1881 Leda ala Barr.; Barrande, pl. 273, figs II/1-3.

1881 Synek antiquus Barr.; Barrande, pl. 275, figs I/1-2.

1968 Pseudocyrtodonta ala Barr. - McAlester, p. 48, pl. 29, figs 6-8.

2012 Pseudocyrtodonta ala Barr. - Steinová, p. 336, fig. 3.

Figure 6. A-C - Pseudocyrtodonta ala (Barrande, 1881). - A, B - articulated specimen, MBHR 2384a; A - left lateral view, $\times 4.8$; B - dorsal view, $\times 7.2$. $\bullet$ - articulated specimen, MBHR 12701 , right lateral view with part of the pseudolateral tooth, $\times 5.3$. $・$ D-F - Pseudocyrtodonta incola $($ Barrande, 1881); D - left valve, MBHR 14442, left dorsolateral view with pseudolateral tooth in posterior part and pseudocardinal teeth in anterior, anterior adductor muscle scar with pedal muscle scar, $\times 10.4$; E - articulated specimen, MBHR 20353, dorsal view, $\times 10.1 ; \mathrm{F}-$ articulated specimen, MBHR 13415, right dorsolateral view, $\times 3.3 . \bullet \mathrm{G}-\mathrm{N}-$ Redonia deshayesi (Rouault, 1851); G - left valve, NM L 22659, left lateral view, $\times 4.4$; H, N - articulated specimen, NM L22656; H - dorsal view, $\times 5.8$; N - right lateral view, $\times 6.0$; I - right valve, LPB 796, neotype, right lateral view with posterior and anterior adductor muscle scars, $\times 3.2 ; \mathrm{J}-$ left valve, MGM643-O, left lateral view, part of the umbo was removed, $\times 5.0 ; \mathrm{K}-$ right valve, LPB 775, left lateral view without umbo with actinodont hinge, $\times 3.5$; L - right valve, L22660, right dorsolateral view, $\times 4.6$; M - right valve, NM L 22658, right dorsolateral view, $\times$ 6.0. A, B - Prague Basin, Bohemia, Rokycany locality, early Darriwilian; C - Prague Basin, Bohemia, Osek 1 locality, early Darriwilian; D, E - Prague Basin, Bohemia, Díly 1 locality, early Darriwilian; F - Prague Basin, Bohemia, Díly 2 locality, early Darriwilian; G, H, L, M, N - Prague Basin, Bohemia, Osek locality, early Darriwilian; I - France, Armorican Massif, Morgat-môle locality, late Darriwilian; J - Spain, Alia Navalpino locality, Darriwilian; K - France, Morgat locality, early Darriwilian. 
Marika Polechová • Bivalves from the Middle Ordovician Šárka Formation (Prague Basin)

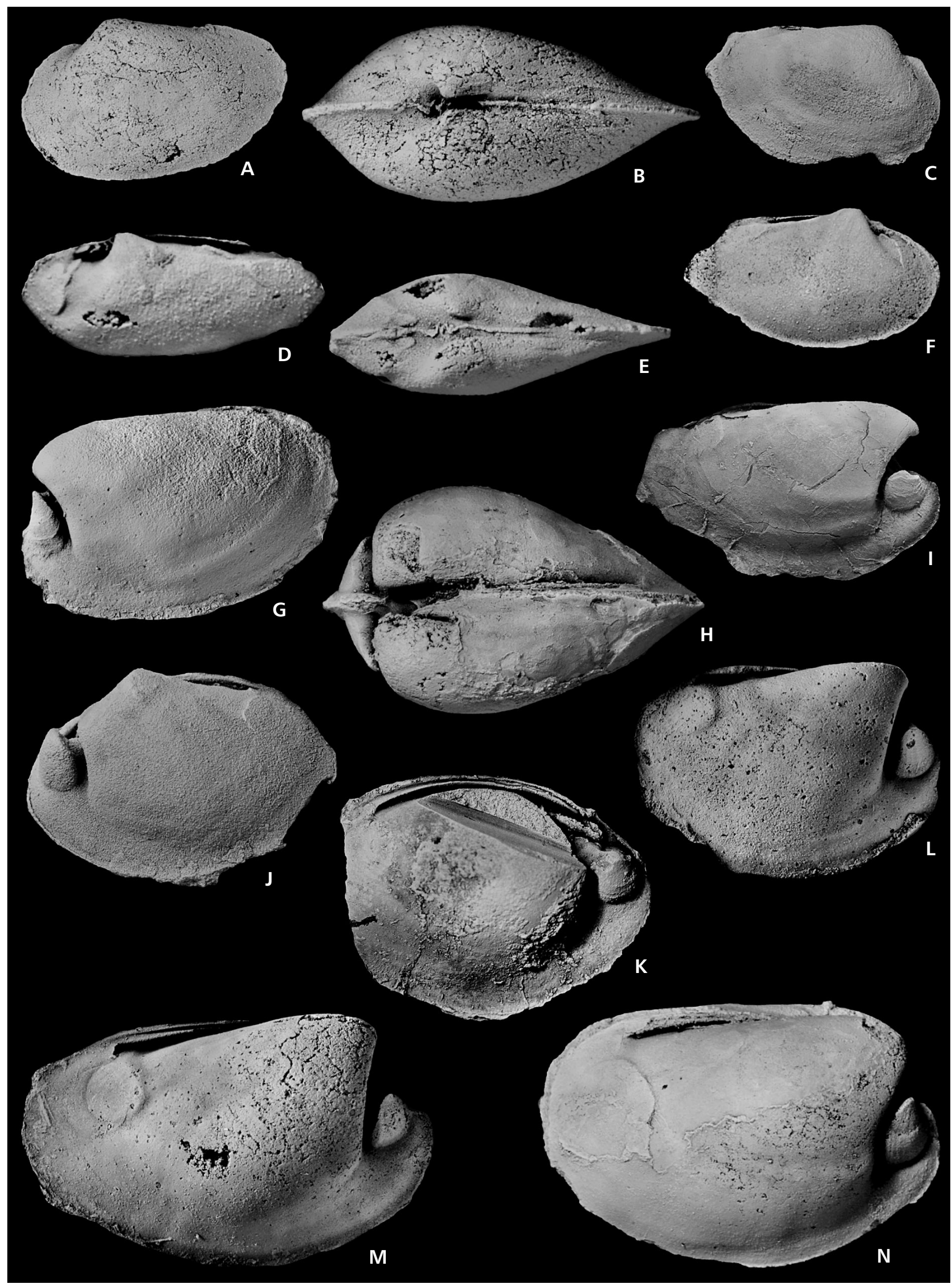


Remarks. - This species has been recently revised and described by Steinová (= Polechová) (2012).

\section{Pseudocyrtodonta incola (Barrande, 1881)}

Figure 6D-F

1881 Leda incola Barr.; Barrande, pl. 270, figs III/1-4.

1934 Pseudocyrtodonta ala Barr. - Pfab, p. 237, pl. 3 (4), fig. 13.

2012 Pseudocyrtodonta incola Barr. - Steinová, p. 338, fig. 4.

Remarks. - This species has been recently revised and described by Steinová (= Polechová) (2012).

\section{Genus Tatula gen. nov.}

Type species. - Tatula petula gen. et sp. nov., Bohemia, Prague Basin, locality Šárka, Middle Ordovician, early and mid Darriwilian, Šárka Formation, by monotypy.

Derivation of name. - Derived from Latin tatula, masculine diminutive from tata $=$ daddy $($ my daddy $=$ tatínek in Czech).

Diagnosis. - Small cycloconchid with numerous pseudolateral and pseudocardinal teeth, the most dorsally placed pseudolateral tooth is short, the other pseudolateral teeth are longer, pseudocardinal teeth in the anterior part are elongated with almost the same size.

Discussion. - Steinová (2012) discussed actinodonts from the Šárka Formation (Pseudocyrtodonta and Redonia). The specimens of Tatula petula gen. et sp. nov. were found recently by the author in the collection of František Hanuš deposited in the National Museum, Prague and therefore this genus could not be mentioned by Steinová (2012). Tatula gen. nov. has very similar hinge to Actinodonta Phillips, 1848 from the Silurian, the difference is in pseudocardinal teeth, which are in Tatula almost the same size, in Actinodonta anteriorly placed pseudocardinals are longer. In Tatula the most dorsally placed pseudolateral tooth is short. Tatula gen. nov. also shows some affinities to Carminodonta Cope, 1996 from the Floian (early Arenig) of Wales and to Ananterodonta Babin \& Gutiérrez-Marco, 1985 from the Darriwilian (Llanvirn) of Spain. Carminodonta could be an ancestor for Tatula and Ananterodonta. All these genera have actinodont hinge with numerous pseudocardinal and pseudolateral teeth (Fig. 8A-C), which differs markedly from the other cycloconchids with simple type of actinodont hinge (Fig. 8D, E) like Pseudocyrtodonta (Fig. 8D) from the Middle and Late Ordovician of Bohemia and Fasciculodonta (Fig. 8E) from the Middle Ordovician (Dapingian-Darriwilian) of China.

Species included. - Tatula petula gen. et sp. nov., early and mid Darriwilian, Prague Basin, Šárka.

\section{Tatula petula sp. nov.} Figures 7G-L, 8A, 9

Holotype. - Internal mould of opened shell figured on Fig. 7G-I, K, L, NM L 41038.

Paratype. - Internal mould of opened shell figured on Fig. 7J, NM L 42218.

Derivation of name. - In honour of my father, Petr = Petula (family nick-name), who brought me up and who supported me in my hobby and occupation - palaeontology.

Type locality. - Bohemia, Prague Basin, Šárka.

Type horizon. - Middle Ordovician, early and mid Darriwilian, Šárka Formation.

Material. - Two opened shells.

Diagnosis. - As for the genus.

Description. - Shell small, equivalve, slightly inequilateral, and broadly ovate. Posterior part is elongated, anterior part rounded. Ventral margin convex. Anterior part of the shell smaller than the posterior part. The umbos located in the anterior part, prosogyrate. Hinge actinodont, in the posterior part

Figure 7. A-F - Concavodonta ponderata (Barrande, 1881). • A, D - left valve, NM L 42215; A - left lateral view, $\times 10.2$; D - left dorsolateral view, $\times 11.2$. B , E - left valve, NM L 42216; B - left lateral view, $\times 5.9$; E - left dorsolateral view, $\times 6.5$. $・$ C, F - right valve, NM L 42217; C - right lateral view, $\times 9.4 ; \mathrm{F}-$ right dorsolateral view, $\times 8.1 . \bullet \mathrm{G}-\mathrm{L}-$ Tatula petula gen. et sp. nov. G, H, I, K, L - holotype, two valves, opened shell, NM L 41038; $\mathrm{G}-$ left valve, left dorsolateral view with actinodont hinge, $\times 13.5 ; \mathrm{H}-$ two valves, dorsal view with actinodont hinge, $\times 11 ; \mathrm{I}-$ right valve with actinodont hinge and adductor muscle scars, $\times 11.2 ; \mathrm{K}$ - left lateral view with actinodont hinge, $\times 12.8 ; \mathrm{L}-$ detail of the actinodont hinge hinge, pseudolateral teeth in the anterior part and pseudocardinal teeth in the posterior part, $\times 24 . \cdot \mathrm{J}-$ paratype, two valves, opened shell, NM L 42218 , lateral view on the two valves, $\times$ 14.5. A, D - Prague Basin, Bohemia, Osek locality, early and middle Darriwilian; B, C, E, F - Prague Basin, Bohemia, Šárka field locality, early and middle Darriwilian; G-L - Prague Basin, Bohemia, Śárka locality, early and middle Darriwilian. 


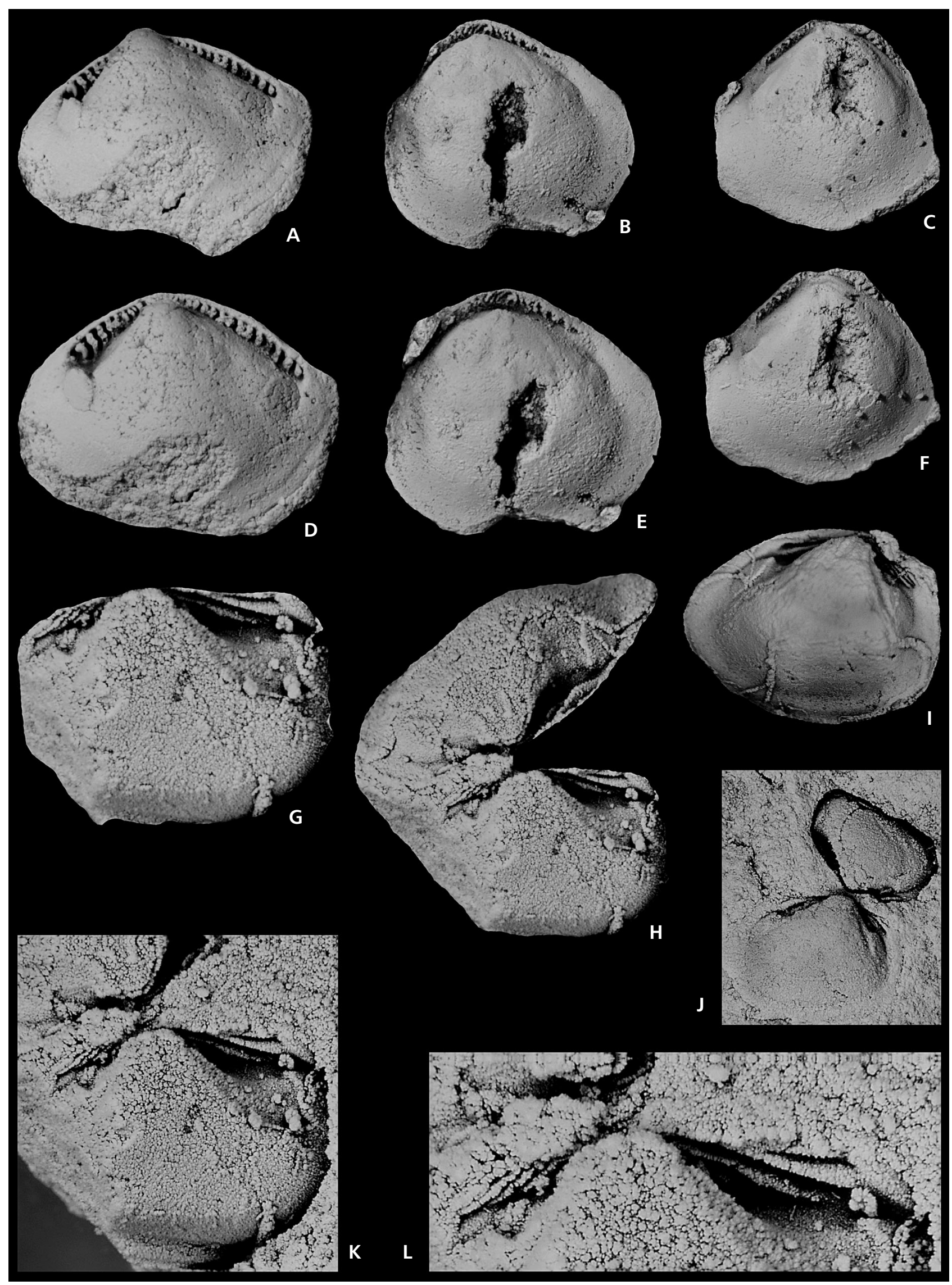




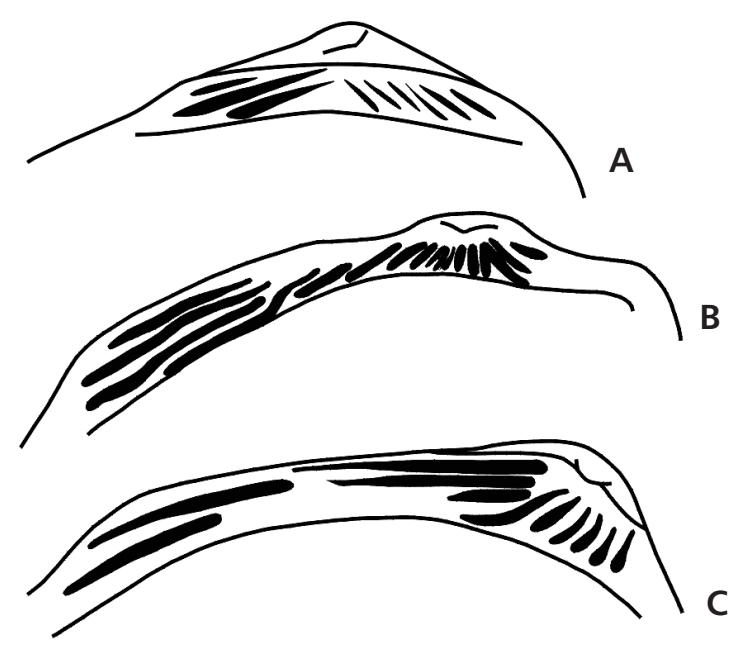

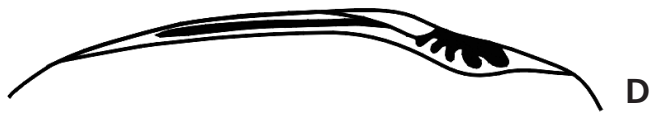

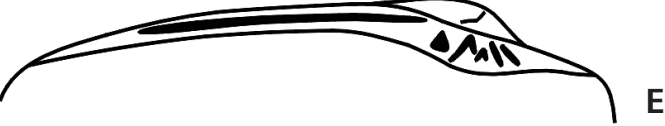

Figure 8. Hinge schemes of the Middle Ordovician Cycloconchidae. $\bullet$ A - Tatula gen. nov. - B - Carminodonta Cope, 1996. - C - Ananterodonta Babin \& Gutiérrez-Marco, 1985. • D - Pseudocyrtodonta Pfab, 1934. • E - Fasciculodonta Fang \& Cope, 2004.

three straight, slender pseudolateral teeth (Fig. 7L). In the anterior part of the hinge six straight, slender pseudocardinal teeth (Fig. 7G, K). Anterior and posterior adductor muscle scars ovate. Inner surface sculpture is smooth, thickness of the shell $0.01 \mathrm{~mm}$. Outer surface sculpture unknown.

\section{Dimensions. -}

$\begin{array}{lrrrr}\text { Specimen } & \text { V } & \text { L } & \text { H } & \text { W/2 } \\ \text { L41038 } & \text { A } & 4.3 & 3.6 & 1.0 \\ \text { L42218 } & \text { A } & 2.8 & 2.1 & 0.9\end{array}$

Superfamily Anodontopsoidea Miller, 1889

Family Redoniidae Babin, 1966

\section{Genus Redonia Rouault, 1851}

Type species. - Redonia deshayesiana Rouault, 1851, France, Armorican Massif, Middle Ordovician, Darriwilian, Postolonnec Formation.

\section{Redonia deshayesi Rouault, 1851}

Figure 6G-N

1851 Redonia deshayesiana Rouault; Rouault, p. 364, figs 1,2 .

1881 Redonia bohemica Barr.; Barrande, pl. 268, figs 1-26.

1881 Nucula faba Barr.; Barrande, pl. 273, figs IV/1-4.

1918 Redonia deshayesiana Rouault. - Born, p. 239, pl. 25, figs $1 \mathrm{a}-\mathrm{f}$.

1918 Redonia deshayesiana var. duvaliana Rouault. Born, p. 341, pl. 25, figs 2a-f.

1934 Redonia deshayesi Roualt. - Gouzien, p. 179.

1950 Redonia bohemica Barrande. - Termier \& Termier, p. 87, pl. 165, figs 1-3, 6-9.

1950 Redonia megalodontoides Termier \& Termier; Termier \& Termier, p. 87, pl. 165, figs 4,5 .
1951 Redonia deshayesiana Rouault. - Gigout, p. 296, pl. 2, fig. 14 .

1966 Redonia deshayesi Rouault. - Babin, p. 246, pl. 10, figs 13-16.

1970 Redonia deshayesi Rouault. - Bradshaw, p. 638, pl. 25, figs 16-21.

1978 Redonia bohemica Barrande. - Pojeta, p. 233, pl. 4, figs $1-4$.

1990 Redonia deshayesi Rouault. - Babin \& Destombes, p. 246, pl. 1, fig. 12.

1991 Redonia deshayesi Rouault. - Babin \& GutiérrezMarco, p. 129, pl. 9, figs a-e.

2003 Redonia deshayesi Rouault. - Babin \& Beaulieu, p. 197 , pl. 3, fig. 1.

Neotype. - Internal mould of the right valve, figured by Babin \& Gutiérrez-Marco (1991) on text-fig. 9d and herein on Fig. 6I, LPB 796.

Type locality. - France, Armorican Massif, Morgat-môle near Crozon.

Type horizon. - Middle Ordovician, late Darriwilian, Postollonec Formation.

Material. - 621 specimens.

Description. - Comprehensive description of this species was given by Babin \& Gutiérrez-Marco (1991). Shell small, medium sized, equivalve, strongly inequilateral, more or less posteriorly elongated. Posterior part of the shell is much larger than the anterior part. Anterior part and posterior part rounded. Ventral margin convex. The umbos strongly in the anterior part, prosogyrate. Hinge actinodont, on the left valve a strong pseudocardinal chevron shaped tooth, two posterior pseudolateral teeth. On the right valve a socket and two posterior pseudolateral teeth 
(Fig. 6K). Anterior adductor muscle scar very deeply inserted with a myophoric plate, posterior adductor muscle scar more or less rounded (Fig. 6I, L, M). One posterior pedal muscle scar is developed antero-ventrally from the posterior adductor muscle scar (Fig. 6M). Inner surface sculpture is smooth, outer surface sculpture with some grooves of growth more marked than other.

$\begin{array}{llrrr}\text { Dimensions. }- & & & & \\ \text { Specimen } & \mathrm{V} & \mathrm{L} & \mathrm{H} & \mathrm{W} / 2 \\ \text { L22657 } & \mathrm{L} & 20.5 & 10.5 & 3.1 \\ \text { LPB 796 (France) } & \mathrm{R} & 19.2 & 10.2 & 3.0 \\ \text { L22663 } & \mathrm{R} & 15.2 & 11.0 & 1.6 \\ \text { JK14668 } & \mathrm{L} & 14.6 & 9.5 & 2.5 \\ \text { L22659 } & \mathrm{L} & 12.6 & 9.0 & 1.9 \\ \text { L22658 } & \mathrm{R} & 12.5 & 7.0 & 2.0 \\ \text { L22656 } & \mathrm{A} & 12.0 & 8.1 & 3.5 \\ \text { L22660 } & \mathrm{R} & 11.8 & 7.2 & 1.8 \\ \text { MGM643-O (Spain) } & \mathrm{L} & 11.1 & - & 1.9 \\ \text { L22662 } & \mathrm{R} & 10.5 & 9.5 & 2.2 \\ \text { L22655 } & \mathrm{A} & 10.2 & 6.2 & 2.5 \\ \text { L22661 } & \mathrm{R} & 10.1 & 6.5 & 2.1 \\ \text { JK 14674b } & \mathrm{R} & 2.9 & 1.2 & 0.7 \\ \text { JK14674c } & \mathrm{A} & 5.6 & 2.1 & 0.8 \\ \text { JK14674d } & \mathrm{R} & 4.3 & 1.9 & 0.7 \\ \text { JK14674e } & \mathrm{L} & 5.9 & 4.5 & - \\ \text { JK 14595 } & \mathrm{L} & 7.5 & 4.2 & 0.7 \\ \text { JK 14670a } & \mathrm{R} & 5.0 & 3.0 & - \\ \text { JK 14670b } & \mathrm{R} & 12.1 & 7.2 & 1.6 \\ \text { JK 14670c } & \mathrm{R} & 11.8 & 6.7 & 0.7 \\ \text { JK 14668a } & \mathrm{L} & 12.6 & 8.3 & 1.9 \\ \text { JK 14675 } & \mathrm{A} & 9.1 & 4.9 & 1.6 \\ \text { JK 14668b } & \mathrm{A} & 13.7 & 7.6 & 1.9 \\ \text { JK 14668c } & \mathrm{R} & 13.8 & 6.9 & 2.5 \\ \text { LPB 775 (France) } & \mathrm{R} & - & - & 2.0 \\ & & & & \end{array}$

Discussion. - Barrande (1881) described the species R. bohemica, which Babin \& Gutiérrez-Marco (1991) consider conspecific with $R$. deshayesi. Material of both species was studied in Bohemia, France and Spain and the opinion of Babin \& Gutiérrez-Marco (1991) is followed in this paper. Very probably $R$. anglica (Salter in Murchison 1859) is also conspecific with $R$. deshayesi. Barrande (1881) already mentioned that $R$. deshayesi is a good example of the species with the high variability mainly in the shape of the shell (short form and long form). Redonia deshayesi was described by Rouault (1851), but the original material was apparently lost and therefore Babin \& Gutiérrez-Marco (1991) designated a neotype from the Postolonnec Formation of Morgat-môle near Crozon, France. Redonia michelae Babin, 1982 from the lower Arenig (Floian) of France is generally smaller and myophoric septum is larger. Redonia suriensis Sánchez \& Babin, 1994 from the Arenig (Floian-Dapingian) of Argentina differs in having a strong

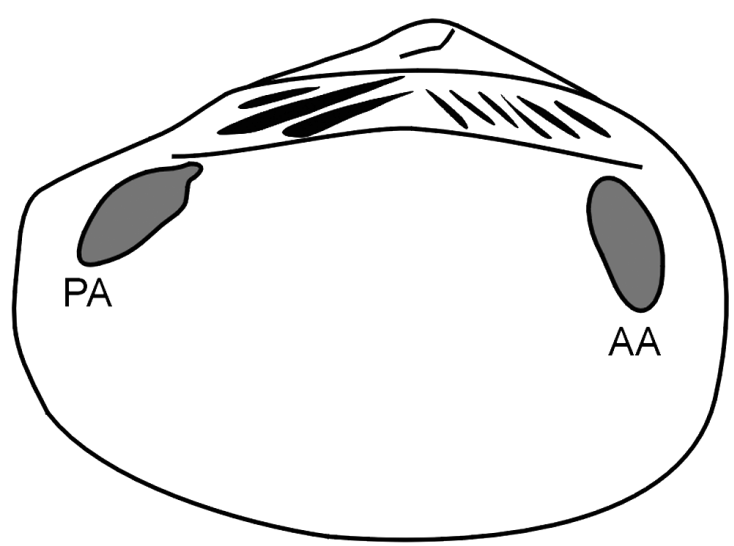

Figure 9. Tatula petula gen. nov. et sp. nov. - left lateral view showing hinge and muscle scars. Key to letter symbols: AA - anterior adductor muscle scar; PA - posterior adductor muscle scar.

umbo, less distinctive myophoric buttress and its pseudocardinal teeth are smaller. Redonia riojana Sánchez, 1997 from the middle Arenig (Dapingian) of Argentina has a less curved umbo and terminal protuberance of the beak.

Occurrence. - Bohemia, Prague Basin, Darriwilian: Kamenný Újezd, Osek, Rokycany, Šárka brickyard, Šárka field, Těškov, Volduchy, Malé Přílepy, Kařízek, Spain, Hesperian Massif, Darriwilian: Cantabrian Zone, West Asturian-leonense Zone, Iberian Cordillera, Central Iberian Zone, Ossa Morena Zone; France, Montagne Noire, early Tremadoc-Floian (early Arenig); France, Armorican Massif, Dapingian-Darriwilian; Morocco, Anti-Atlas, Darriwilian; Bolivia, Tarija area, early Darriwilian.

Subcohort Cardioni Férussac, 1822 (in Férussac \&

Audebard 1822) (= Euheterodonta Giribet \& Distel, 2003) Infrasubcohort Lucinidia Gray, 1854

Superfamily Babinkoidea Horný, 1960

Family Babinkidae Horný, 1960

\section{Genus Babinka Barrande, 1881}

Type species. - Babinka prima Barrande, 1881, Bohemia, Prague Basin, Osek, Middle Ordovician, early and middle Darriwilian, Šárka Formation.

\section{Babinka prima Barrande, 1881}

Figure 10A-F, H

1881 Babinka prima Barr.; Barrande, pl. 266, figs VI/1-16. 1935 Babinka prima Barr. - Thoral, p. 162, pl. 13, figs 4, 5. 1954 Babinka prima Barr. - Vokes, p. 235, fig. 1. 1960 Babinka prima Barr. - Růžička \& Prantl, p. 48. 1960 Babinka prima Barr. - Horný, p. 480, pl. 1. 1962 Babinka prima Barr. - Vogel, p. 235, pl. 5, figs 5, 6. 
1965 Babinka prima Barr. - McAlester, p. 242, pl. 26, figs 3-12; pl. 27, figs 2-5; pl. 28, figs 1-4, 9-14.

1969 Babinka prima Barr. - McAlester, p. 491, fig. E1.

1969 Babinka prima Barr. - Soot-Ryen, p. 175, pl. 34, figs 6-8.

1971 Babinka prima Barr. - Pojeta, p. 12, pl. 1, figs 12-14.

1977 Babinka prima Barr. - Babin, p. 52, pl. 4, figs 1-14; pl. 5, figs 1-3, 6, 9, 10.

1978 Babinka prima Barr. - Pojeta, p. 242, pl. 14, figs 10, 11.

1982 Babinka prima Barr. - Babin, p. 40, pl. 11, figs 8, 9.

1990 Babinka prima Barr. - Babin \& Destombes, p. 244, pl. 2, fig. 2.

1991 Babinka prima Barr. - Babin \& Gutiérrez-Marco, p. 128 , pl. 5 , fig. 5 .

1997 Babinka prima Barr. - Cope, p. 738, pl. 3, figs 3, 6.

1999 Babinka prima Barr. - Cope, p. 484, pl. 2, fig. 2.

2008 Babinka prima Barr. - Giribet, p. 119, fig. 6B, C.

Lectotype. - (SD by Růžička \& Prantl in 1960, p. 48.) Internal mould of the shell with conjoined valves, figured by Barrande (1881) on pl. 266, as figs VI/7-9, NM L 27086.

Paralectotypes. - Internal moulds of the shell, figured by Barrande (1881) on pl. 266, as figs VI/1 - NM L 27087, VI/2-3 - NM L 27088, VI/4-6 - NM L 41033, VI/10-12 NM L 41034 and VI/13-15 - NM L 41035.

Type locality. - Bohemia, Prague Basin, Osek.

Type horizon. - Middle Ordovician, early and mid Darriwilian, Šárka Formation.

Material. - 115 specimens.

Description. - Babinka prima was figured and described by many authors, especially by Barrande (1881), McAlester (1965) and Babin (1977). Shell broadly elliptical, medium-sized, equivalve, more or less inequilateral. Anterior part of the shell is slightly larger than posterior part. Anterior part and posterior part rounded. Ventral margin convex. The umbos located almost in the middle of the shell or slightly in the posterior part. Hinge with one large, triangular, cardinal tooth on the right valve and two small cardinal teeth on the left valve (Fig. 10E, D). Anterior and posterior adductor muscle scars elongated (Fig. 10A, D) and connected ventrally by integripalliate line. Between adductor muscle scars is a range of small vertically elongated pedal muscle scars, the ventral part of these small muscle scars is rounded and more deeply impressed (Fig. 10A, D, E). Ventrally of the small muscle scars are impressed numerous very small dot like muscle scars interpreted by McAlester (1965) as gill attachment muscle scars. Outer surface sculpture of commarginal ridges.

$\begin{array}{llrrr}\begin{array}{l}\text { Dimensions. - } \\ \text { Specimen }\end{array} & \text { V } & \text { L } & \text { H } & \text { W/2 } \\ \text { NM L 41035 } & \text { R } & 24.5 & 18.0 & 2.5 \\ \text { JK 14667 } & \text { R } & 23.1 & - & 2.2 \\ \text { NM L 41033 } & \text { R } & 21.1 & 13.6 & 2.2 \\ \text { NM L 27086 } & \text { L } & 21.0 & 15.8 & 2.1 \\ \text { NM L 41034 } & \text { L } & 20.5 & 14.1 & 1.9 \\ \text { NM L 27089 } & \text { L } & 19.2 & 13.2 & - \\ \text { NM L 27087 } & \text { L } & 11.6 & 9.1 & 2.0 \\ \text { NM L 27088 } & \text { L } & 9.0 & 7.9 & -\end{array}$

Discussion. - McAlester (1965) considered the larger part of the shell as anterior part. Starobogatov (1971) claimed that Babinka has the opposite orientation (the larger part is posterior). This opinion was dismissed by Pojeta (1978) who followed McAlester (1965). Also Cope (1999) followed the opinion of McAlester. Sánchez (2008) described Babinka notia with diagnosis posteriorly elongated Babinka, and therefore it seems that Sánchez followed the opinion of Starobogatov, but the orientation is not further discussed. Babinka prima was considered by several authors as the genus directly linked to the monoplacophorans (e.g. Horný 1960, McAlester 1965), mainly because of multiple pedal musculature. But this feature is not unique for Babinka, it was shown that multiple pedal musculature is known in more bivalves. McAlester (1965) and Carter et al. (2000) assigned Babinka close to Ilionia Billings, 1874, which they considered as the oldest known deep burrowing suspension feeding bivalve. Taylor \& Glover (2000) concluded that lucinid character of Babinka is doubtful, because they described the anterior respiratory pouch in the lucinoids which in Babinka is apparently absent. Recent lucinoids also show enlarged and elongated anterior adductor muscle scar, in Babinka the anterior adductor muscle scar is only slightly larger than posterior adductor muscle scar. Babin (1982) in Babin et al. 1982 and Cope (1997) placed Babinka within the order Actinodontoida. B. oelandensis Soot-Ryen, 1969 from the late Arenig (Darriwilian) of Sweden differs from B. prima slightly in the shape and more dorsally placed pedal muscle scars.

Occurrence. - Bohemia, Prague Basin, early and mid Darriwilian: Díly, Drahouš, Kamenný Újezd, Mýto, Osek, Rokycany, Šárka brickyard, Šárka field; Spain, Hesperian Massif, Darriwilian: Cantabrian Zone, West Asturian-leonense Zone, Iberian Cordillera, Central Iberian Zone, Ossa Morena Zone; France, Montagne Noire, early Tremadoc-Floian (early Arenig); France, Armorican Massif, Dapingian-Darriwilian; Wales, Carmarthenshire, Darriwilian; England, Shelve Inlier, Darriwilian; Morocco, Anti-Atlas, Darriwilian. 
Family Coxiconchiidae Babin, 1977

\section{Genus Coxiconchia Babin, 1966}

Type species. - Lyonsia britannica Rouault, 1851, France, Armorican Massif, Middle Ordovician, Darriwilian, Postolonnec Formation.

\section{Coxiconchia britannica (Rouault, 1851)}

Figure 10G, I-O

1851 Lyonsia britannica Rouault; Rouault, p. 362.

1856 Sanguinolites pellicoi de Verneuil \& Barrande; p. 992, pl. 27, figs 4, 4a.

1889 Orthonota? britannica (Rouault). - Bigot, p. 80.

1912 Sanguinolites pellicoi de Verneuil \& Barrande. Douvillé, p. 465, figs 65, 66.

1918 Sanguinolites pellicoi de Verneuil \& Barrande. Born, p. 341, pl. 24, figs 3a, b.

1935 Sanguinolites pellicoi de Verneuil \& Barrande. Thoral, p. 173.

1966 Coxiconchia britannica (Rouault). - Babin, p. 282, pl. 11, fig. 13.

1966 Coxiconchia pellicoi (de Verneuil \& Barrande). - Babin, p. 282, pl. 11, fig. 6, text-fig. 73 .

1977 Coxiconchia britannica (Rouault). - Babin, p. 57, pl. 1-3, 5 (figs 4, 5, 7, 8, 11, 12).

1995 Coxiconchia britannica holubi Kříž; p. 46, pl. 1, figs $1-11$.

Neotype. - (SD, Babin 1966.) Internal mould of articulated shell figured by Babin (1966) on pl. 11 as fig. 13.

Type locality. - France, Armorican Massif, Ille et Vilaine, Guichen, Traveusot.

Type horizon. - Middle Ordovician, late Darriwilian, Postolonnec Formation.

Material. - Two right valves and two left valves, twelve specimens with conjoined valves.

Description. - Comprehensive description was given by Kříž (1995).

\section{Dimensions. -}

$\begin{array}{lrrrr}\text { Specimen } & \text { V } & \text { L } & \text { H } & \text { W/2 } \\ \text { JK 2998 (France) } & \text { R } & 37.1 & 21.8 & 5.7 \\ \text { JK18012 (France) } & \text { R } & 35.1 & 20.1 & 5.9 \\ \text { MBHR 5498 } & \text { A } & 32.6 & 18.0 & 6.0 \\ \text { MBHR 5499 } & \text { A } & 30.9 & 17.6 & 5.3 \\ \text { MGM644-O (Spain) } & \text { A } & 30.8 & 16.8 & 5.4 \\ \text { MBHR 5501 } & \text { A } & 28.3 & 18.2 & 5.7 \\ \text { MBHR 12689 } & \text { R } & - & 16.8 & 4.7\end{array}$

$\begin{array}{lrrrr}\text { MBHR 5500 } & \text { A } & 26.5 & 16.2 & 5.0 \\ \text { JK 2999 } & \text { A } & - & 16.0 & 5.0 \\ \text { MBHR 10992 } & \text { A } & 25.4 & 15.7 & 4.0 \\ \text { CW 2 } & \text { A } & 25.5 & 15.2 & 5.0 \\ \text { CW 3a } & \text { A } & 28.6 & 13.9 & 6.1\end{array}$

Discussion. - Kříž (1995) considered C. britannica holubi different from $C$. britannica britannica in its larger shells, deeper and relatively larger anterior adductor muscle scars and visceral muscle scars and in the shape of posterior part, which is transversely elliptic. All these features are considered here as intra-specific variability. C. britannica is abundant in Spain, and among the specimens the variability is really high and therefore herein Coxiconchia britannica is regarded as being without subspecies. C. britannica differs from C. guiraudi (Thoral, 1935) from the Arenig (Floian) of France mainly in the larger size, other features are somewhat problematic and Babin et al. (1982) admitted that to distinguish these two species is very difficult. C. sellaensis Sánchez \& Babin, 2005 from the Arenig (Floian) of Bolivia and Argentina has a well-developed subumbonal carina and posteroventral slope. C. sellaensis from Argentina also shows radial sculpture. C. babini Sánchez, 2005 from the Tremadoc of Argentina has a smaller size of the shell and shows fewer accessory subumbonal muscles and an ill-defined posterior adductor muscle scar.

Occurrence. - Bohemia, Prague Basin, early and mid Darriwilian: Rokycany, Osek, Sedlec, Drahouš; Spain, Hesperian Massif, Darriwilian: Central Iberian Zone, West Asturian-leonense Zone; France, Armorican Massif, Darriwilian; Wales, Camnant section, Darriwilian; Morocco, Anti-Atlas, Darriwilian; Bolivia, Tarija area, early Darriwilian.

Infraclass Pteriomorphia Beurlen, 1944

Cohort Mytilomorphi Férussac, 1822 (in Férussac \& Audebard 1822)

Order Mytilida Férussac, 1822 (in Férussac \& Audebard 1822)

Superfamily Modiolopsoidea Fischer, 1886

Family Modiolopsidae Fischer, 1886

\section{Genus Modiolopsis Hall, 1847}

Type species. - Pterinea modiolaris Conrad, 1838, U.S.A, New York, Ordovician, Pulaski Formation.

\section{Modiolopsis sp.}

Figure 11A-H, J

Material. - Seven left valves, eight right valves and six articulated specimens. 
Description. - Shell small in size (maximum $\mathrm{L}=9.2$ ), elongated, equivalve, inequilateral. Shells are inflated with no distinct umbonal ridge. Anterior part evenly rounded, posterior part of the shell larger than anterior part. Maximum height is reached approximately in the third quarter of the shell length from anterior. Umbos prominent and prosogyrate. Dorsal margin is long, more than one half of the shell length, straight. Ventral margin is convex. Posterior margin evenly rounded. Hinge plate edentulous, anterior muscle scar rounded (Fig. 11D). Outer surface sculpture composed of irregularly spaced growth (Fig. 11G).

$\begin{array}{llrrr}\text { Dimensions. - } & & & & \\ \text { Specimen } & \text { V } & \text { L } & \text { H } & \text { W/2 } \\ \text { NM L 41028 } & \text { L } & 9.2 & 5.8 & 1.9 \\ \text { NM L 41030 } & \text { R } & 7.0 & 4.0 & 0.7 \\ \text { NM L 41031 } & \text { R } & 6.5 & 4.2 & 1.2 \\ \text { NM L 41036a } & \text { L } & 9.4 & 6.3 & 2.1 \\ \text { NM L 41036c } & \text { R } & 9.9 & 6.2 & 2.6 \\ \text { NM L 41037a } & \text { R } & 14.6 & 8.8 & 2.1 \\ \text { NM L 41029 } & \text { A } & - & 8.6 & 2.2\end{array}$

Discussion. - More than 163 species were classified from the Ordovician of North America under Modiolopsis Hall, 1847 by Pojeta (1971). In general, edentulous hinge and modiolophorm shape of the shell are only significant characters for this genus and therefore specific classification is very difficult (Kříž \& Steinová 2009). This evolutionary important genus is well known from the Ordovician of Argentina (Sánchez 1990), France (Babin 1966, Babin \& Beaulieu 2003), Morrocco (Babin \& Destombes 1990), North America (Pojeta 1971), Spain (Babin \& Gutiérrez-Marco 1991) and Wales (Cope 1996). Barrande (1881) figured some species of Modiolopsis only from the Late Ordovician of Bohemia. Modiolopsis sp. described here from the Middle Ordovician differs from the type species Modiolopsis modiolaris (Conrad, 1838) from the Late Ordovician of North America in more elongated and larger shells, deeply impressed anterior and posterior adductor muscle scars and the pallial line. M. draboviensis Barrande, 1881 from the Late Ordovician, Sandbian, Letná Formation seems to be very similar to Modiolopsis sp. Modiolopsis drabovi- ensis is only more posteriorly elongated. "Modiolopsis" primula Barrande, 1881 from the Late Ordovician, Sandbian, the Letná Formation has a higher and shorter shell. M. veterana Barrande, 1881 from the Late Ordovician, Sandbian, Zahořany Formation has the prominent umbonal ridge. This species probably does not belong to the genus Modiolopsis. M. faba Barrande, 1881 from the Late Ordovician, late Katian, Králův Dvůr Formation has the same width of the anterior and posterior part. M. lenticularis Barrande, 1881 from the Late Ordovician, late Katian, Králův Dvůr Formation shows more rounded shell and very probably this species does not belong to Modiolopsis. M. minuta Barrande, 1881 from the Late Ordovician, Katian, Králův Dvůr Formation has well developed posterior wing, separated by the radial sulcus and probably it should not be assigned to Modiolopsis. M. tumescens Barrande, 1881 also from the Králův Dvůr Formation differs from Modiolopsis sp. in the shape of the shell. M. pragensis Kříz \& Steinová, 2009 from the Late Ordovician, Hirnantian, Kosov Formation has a less pronounced umbo. M. cuyana Sánchez, 1990 from the Hirnantian of Argentina seems to be very similar, but it lacks a prominent anterior lobe. M. elegantulus Sharpe, 1853 from the Middle Ordovician of Portugal and Armorican Massif has a concavo-convex ventral margin of the shell.

Occurrence. - Bohemia, Prague Basin, early and mid Darriwilian: Šárka villa.

Cohort Ostreomorphi Férussac, 1822 (in Férussac \&

Audebard 1822)

Subcohort Arcioni Gray, 1854

Order Cyrtodontida Scarlato \& Starobogatov, 1971

(in Nevesskaya 1971)

Suborder Cyrtodontidina Scarlato \& Starobogatov, 1971

(in Nevesskaya 1971)

Superfamily Cyrtodontoidea Ulrich, 1894 (in Ulrich \& Scofield 1894)

Family Cyrtodontidae Ulrich, 1894 (in Ulrich \& Scofield 1894)

Subfamily Cyrtodontinae Ulrich, 1894 (in Ulrich \&

Scofield 1894)

Figure 10. A-F, H - Babinka prima Barrande, 1881. • A, D - right valve, NM L 41035; A - right lateral view with impressions of adductor muscle scars and row of accessory muscle scars between adductor muscle scars, $\times 2.0 ; \mathrm{D}-$ detail of the hinge and adductor and accessory muscle scars, $\times 3.1$. $\bullet \mathrm{B}, \mathrm{E}-$ left valve, NM L 41034; B - left lateral view, $\times 2.4$; E - detail of the hinge, $\times 3.2$. $\bullet \mathrm{C}-$ left valve, NM L 27089 , left lateral view, $\times 2.5$. $\bullet$ - left valve, NM L27086, lectotype, left lateral view, $\times 2.4 \cdot \bullet \mathrm{H}$ - right valve, NM L41033, right lateral view, $\times 2.2 . \bullet \mathrm{G}-\mathrm{J}-$ Coxiconchia britannica $($ Rouault, 1851). G, J - left valve, CW 2; G - dorsal view, $\times 2.4 ; \mathrm{J}-$ right lateral view with adductor and accessory muscle scars, $\times 2.6 ; \mathrm{I}-\mathrm{left}$ valve, MGM644-O, left lateral view, $\times 1.8$. $\bullet \mathrm{K}-$ articulated specimen, $\mathrm{CW} 3 \mathrm{a}$, dorsal view, $\times 3 . \bullet \mathrm{L}-$ part of the right valve, $\mathrm{CW} 3 \mathrm{~b}$, outer surface sculpture, $\times 2.4$. - M-O - right valve, JK 18012; M - posterior adductor muscle scar with posterior retractor, $\times 2.2 ; \mathrm{N}-$ right lateral view, $\times 1.7$; O - anterior adductor muscle scar with protractor, $\times 2.8$. A-H, J, K, L - Prague Basin, Bohemia, Osek locality, early and mid Darriwilian; I - Spain, Alia Navalpino locality, Darriwilian; M-O - France, Morgat locality, late Darriwilian. 


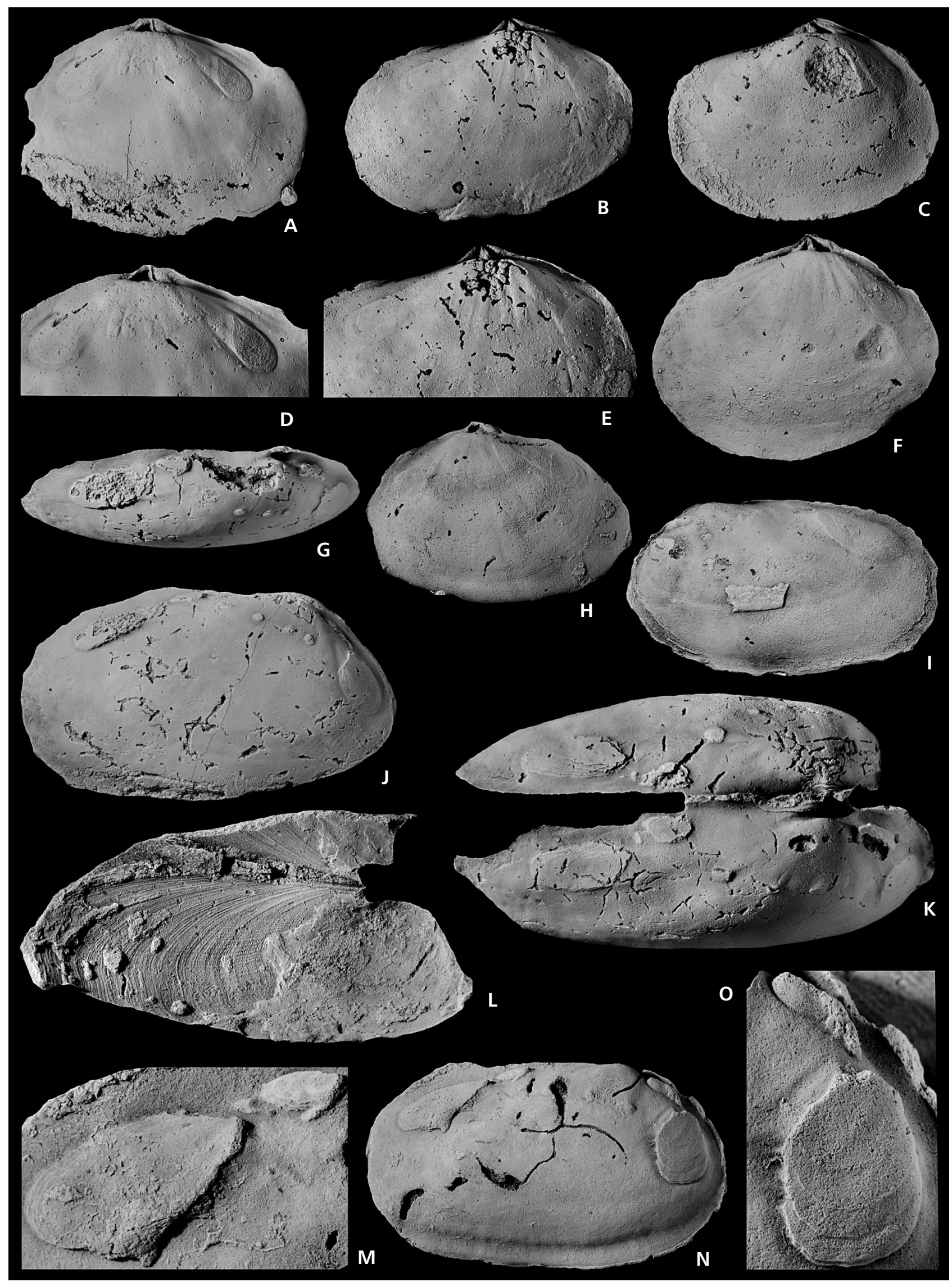




\section{Genus Cyrtodonta Billings, 1858}

Type species. - Cyrtodonta rugosa Billings, 1858, Canada, Ordovician.

\section{Cyrtodonta sp.}

Figure 11I-L

Material. - One left valve.

Description. - Shell small, rectangle, equivalve, inequilateral. Anterior part evenly rounded, smaller, posterior part straight and elongated. Ventral margin slightly concave in the middle of the shell. Umbos not prominent, prosogyrate. Dorsal margin is straight and long, more than one half of the shell length. Posterior margin badly preserved. Hinge plate with one long tooth in the posterior part, and one long and smaller tooth in the anterior part (Fig. 11K, L). Muscle scars and pallial line not developed. Inner surface sculpture composed of irregularly spaced growth. Outer surface sculpture unknown.

\section{Dimensions. -}

$\begin{array}{llrrr}\text { Specimen } & \text { V } & \text { L } & \text { H } & \text { W/2 } \\ \text { NM L 41036 } & \text { L } & 10.5 & 6.3 & 2.4\end{array}$

Discussion. - Cyrtodonta is known from the Ordovician of Canada, Wales, Ireland, Australia, Sweden, China and United States. Cyrtodonta sp. from Bohemia is similar in the shape to $C$. staffordae Pojeta \& Gilbert-Tomlinson, 1971 from the Ordovician of Australia and to C. cf. staffordae from the Lower Ordovician of Wales. One ill-preserved specimen from Bohemia does not allowe precise determination and therefore it is left in open nomenclature.

Occurrence. - Bohemia, Prague Basin, early and mid Darriwilian: Šárka villa.

\section{Functional morphology of the Ordovician Protobranchia}

\section{Orientation of the shell}

A very problematic feature in the Ordovician Protobranchia is the orientation of the shell. Recent Protobranchia show both orientations (larger part as anterior - Nuculidae or larger part as posterior - Nuculanidae). To determine anterior and posterior ends of the shell is easy in the Recent bivalves (pallial sinus is in the posterior part of the shell, foot is in anterior part). The situation is totally different in the Ordovician Protobranchia because of poorly studied or specialized groups, especially where the internal morphology of the shell is ambiguous, weakly impressed or limited by preservation of material. Driscoll (1964) was interested in the accessory muscle scars of bivalves and tried to use them as the indicator of the shell orientation. He pointed out that it is necessary to recognise precisely all the accessory muscle scars (anterior protractor, anterior retractor, posterior retractor, dorso-median muscle scar, ventromedian muscle scar and others). The success of this method is mostly limited by insufficient preservation. In the Ordovician bivalves from Bohemia, the muscle scars close to the adductor scars (probably retractor and protractor pedal muscle scars) are preserved relatively often, but other accessory muscle scars (mainly in umbo region) are preserved very rarely. Bradshaw \& Bradshaw (1971) used the palaeotaxodont hinge as a guide to orientation with conclusion that larger teeth on one side indicate the anterior part. Some Protobranchia have often teeth of the same size (e.g. $P$. dispar) and it is impossible to use this method for them. Bailey (2009) proposed a new alternative, in the case that it is difficult to recognize the orientation of the shell, to avoid subjective terms like anterior or posterior. We can use terms, which describe bivalves with reference to the shell axes, shell extremities and shell dorsum and ligamental placement.

\section{Hinge}

Pfab's classification (1934) of the Protobranchia from the Prague Basin was based mainly on characters of the hinge. He recognized six hinge types according to their teeth's shape and if the apex of chevron-shaped teeth points toward the umbo or away from the umbo. According to Babin (1966) and Carter et al. (2012) the Protobranchia possess different types of taxodont teeth, including convexodont, concavodont, orthomorphodont, diconcavodont, diconvexodont, convexoconcavodont, and concavoconvexodont (Fig. 12). Babin (1966) considered the inclination to the umbo as systematically important character and Sánchez

Figure 11. A-H, J - Modiolopsis sp. • A - left valve, NM L 41028, left lateral view, × 5.3; B - articulated specimen, NM L 41029, left lateral view, $\times 3.4$; C - right valve, NM L 41030, right lateral view, $\times 6.7$; D - left valve, NM L 41036a, left lateral view with anterior adductor muscle scar, $\times 6.5$; E, G - left valve, NM L 41037a; E - left lateral view, $\times 6.4 ; \mathrm{G}$ - outer surface sculpture, $\times 6.1$; F - right valve, NM L 41031, right lateral view; H, J - right valve, NM L 41036c; H - right lateral view, × 8.8; J - right dorsolateral view, $\times 6.5$. $-\mathrm{I}, \mathrm{K}, \mathrm{L}-$ Cyrtodonta sp., left valve, NM L 41036b; I - dorsal view, $\times 8.1 ; \mathrm{K}-$ left lateral view, $\times 6.2 ; \mathrm{L}-$ left dorsolateral view with hinge, $\times 7.1$. A-L - Prague Basin, Bohemia, Śárka brickyard locality, early and mid Darriwilian. 


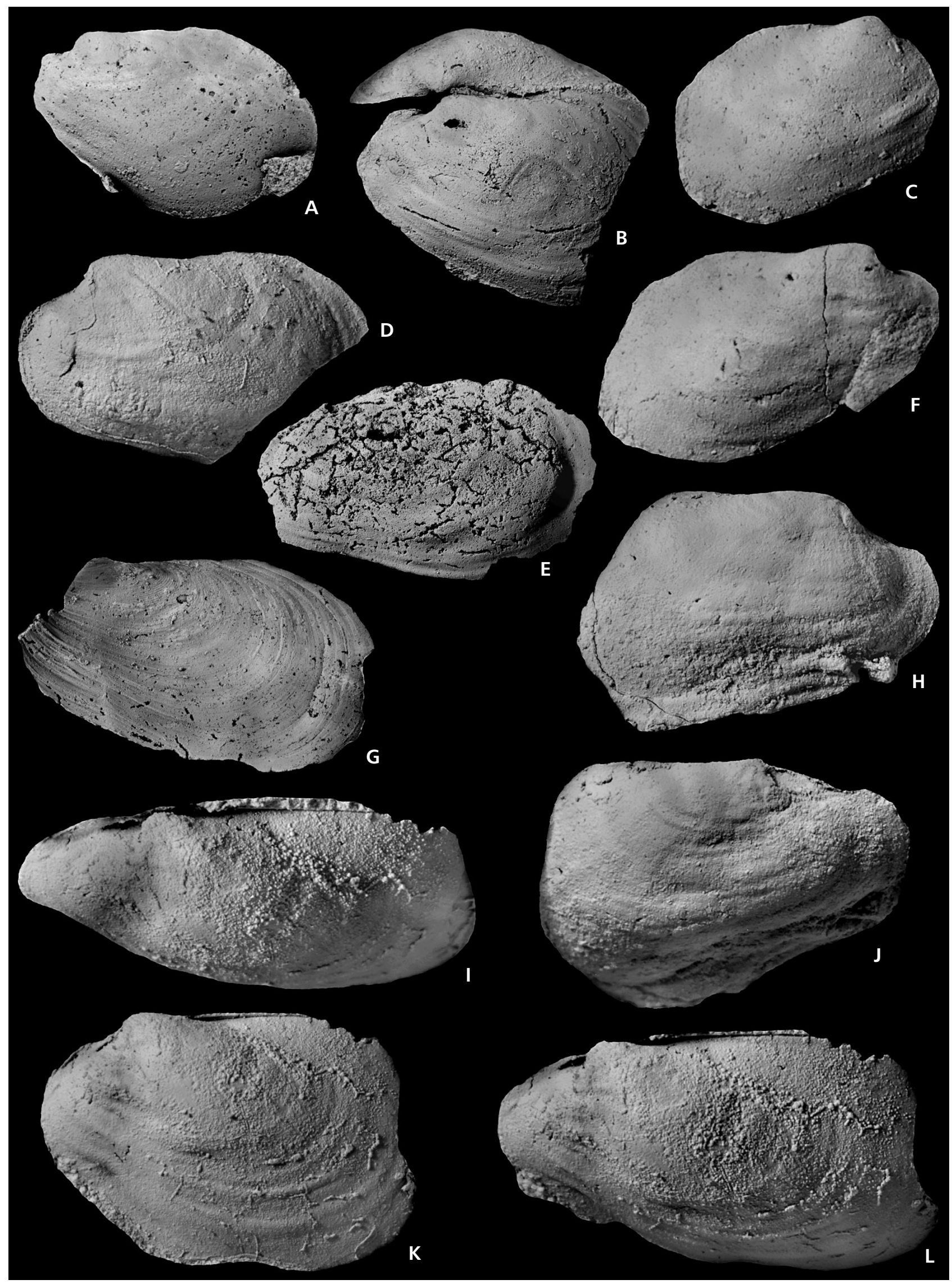




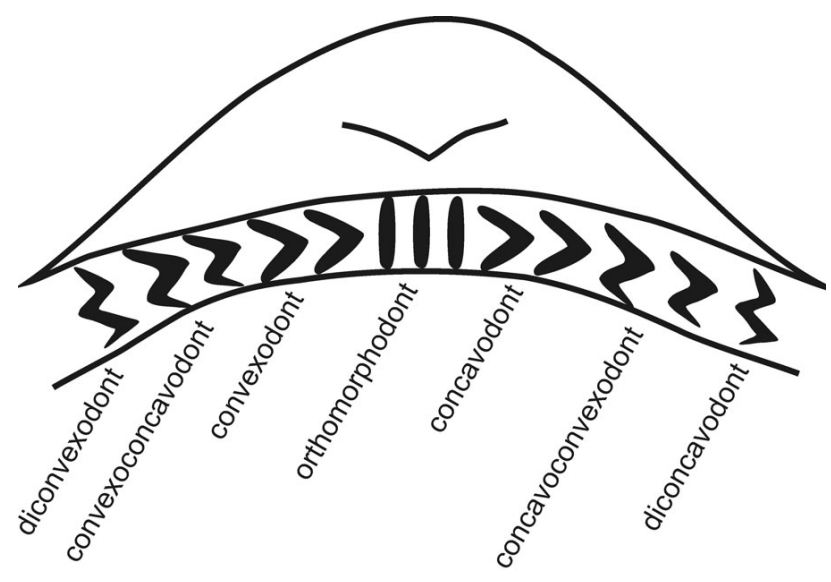

Figure 12. Teeth in taxodont hinge according to Carter et al. (2012).

(1999) established two subfamilies (Praenuculinae and Concavodontinae) mainly according to how their teeth incline to the umbo. On the contrary Pojeta (2007) is of the opinion that the direction to which the apex end of chevron-shaped teeth points is not a significant taxobasis. Also according to Cope (1999) a more important character is the discordance between anterior and posterior part of the shell and for Carter et al. (2000) the size of the teeth. The Protobranchia from the Middle Ordovician of Bohemia show three types of the taxodont hinge (Fig. 5A-D). $P$. bohemica and $P$. applanans have the same type of the hinge, but it is not possible to determine them in Praenuculinae or Concavodontinae, the hinge in anterior part is clearly convexodont, but the hinge in the posterior is not convexodont or concavodont, it is rather orthomorphodont. In $C$. ponderata the anterior teeth are diconvexodont, which is different from the diagnosis for Concavodontinae. On the other side $P$. dispar can be determined to Praenuculinae according to Sánchez (1999) without doubt. This character of the orientation of teeth to umbo or out from the umbo is mostly important for distinguishing species, but its value for higher systematic levels is probably overestimated.

The types of taxodont teeth in Ordovician bivalves show high variability. On the contrary, when I studied recently the Recent genera of the Protobranchia in the Natural History Museum in Paris and in the Smithsonian Institution in Washington D.C., they predominantly show convexodont teeth; the most anterior and posterior teeth and the teeth under the umbo are often orthomorphodont. Only some species of the genera Tindaria Bellardi, 1875 and Malletia Des Moulins, 1832 show concavodont and diconcavodont teeth. Generally, the taxodont teeth in the Recent Protobranchia are simpler.

Carter et al. (2000) used new term heterotaxodont hinge, which mean the hinge with the anterior teeth, which are abruptly much larger than the posterior teeth. He used Praeleda subtilis Cope, 1999 as an example. Carter et al. (2000) redefined the term gradidentate hinge in which the teeth gradually change in size along the tooth row, typically becoming larger away from the beak. The more distal teeth may then gradually decrease in size, like example it can be shown the Late Ordovician Similodonta similis Ulrich, 1892. The other term, which could be a little confusing in comparing with two previous, is cardiolariid hinge. This is a hinge with posterior gradidentate teeth overlapping larger, subumbonal, radiating hinge teeth. Cardiolaria beirensis (Sharpe, 1853) is a good example. The Bohemian Middle Ordovician Protobranchia shows both gradidentate hinge and heterotaxodont hinge. $P$. dispar shows slightly gradidentate teeth (under the umbo the teeth are the smallest), in $P$. bohemica and $P$. applanans is the situation more complicated, in most specimens the hinge is gradidentate, but some specimens (Figs 3M, 4B) show rather heterotaxodont hinge.

\section{Muscle scars}

Heath (1937) and Yonge (1939) precisely described the system of muscles and the muscle scars in the Recent Protobranchia. Driscoll (1964) compared pedal and other accessory muscle scars on the recent genera Acila and Nucula and on the extinct genera Ctenodonta and Nuculopsis. He tried to use the muscle scars as an indicator of the orientation for bivalves. According to Driscoll (1964) the Ordovician Protobranchia shows more numerous accessory muscle scars than the recent Protobranchia and this opinion was based mainly on species Myoplusia bilunata (Barrande, 1881). According to my observation the preservation of pedal muscle scars and other accessory muscle scars on the shell in Recent bivalves is very rare. Kř́ž (1974 MS) and Kř́ž (1995, fig. 3) described and figured numerous accessory muscles in Leionucula mirifica (Dall, 1907) on before unknown wet syntype material dredged in 1906 Japan Hokkaido Island offshore and deposited in the U.S. National Museum, Smithsonian Institution. Accessory muscle scars in Leionucula are more numerous than in specimens of Myoplusia bilunata (Barrande, 1881) (Fig. 13). But it seems that accessory muscle scars in the Ordovician bivalves are generally larger.

Bradshaw (1970) studied and figured muscle scars in Cardiolaria and Praenucula, the species Praenucula ciae and Praenucula costae show almost the same muscle scars pattern like all the species of Praenucula from Bohemia (the anterior adductor muscle scar mostly larger with joined anterior pedal muscle scar, the posterior muscle scar mostly smaller with separated posterior pedal muscle scar and the accessory muscle scar very often placed in the umbo region in triangl pattern). According to Heath (1937) the ventro-median and dorso-median accessory muscle scars in the Recent protobranchs represent the attachment of visceral retractors, which reinforced the action of pedal 


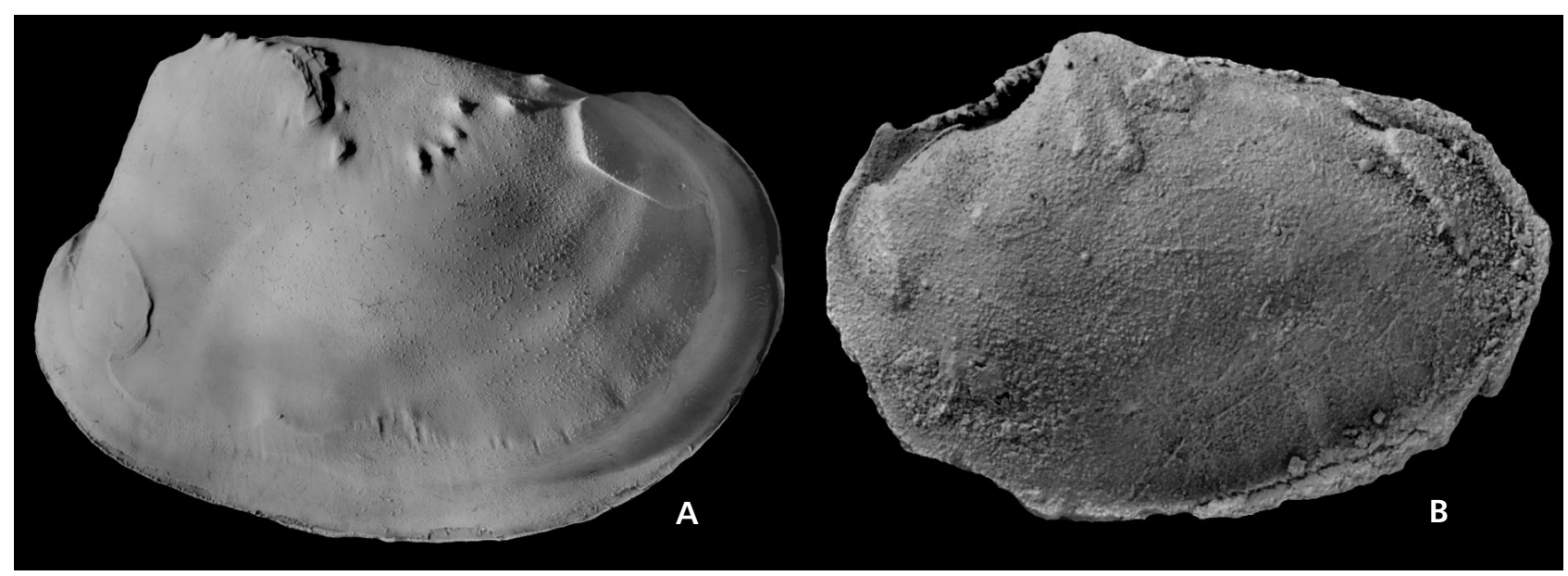

Figure 13. Muscle scars in Leionucula mirifica and Myoplusia bilunata. • A - Leionucula mirfica (Dall, 1907), JK 18425, latex cast after USNM 363746, left valve, left lateral view with numerous accessory muscle scars, $\times 2.2 \cdot \bullet B-$ Myoplusia bilunata (Barrande, 1881), NM L 27130, right valve, right lateral view with accessory muscle scars, $\times 9.6$.

retractors or provided a firm attachment of the pericardial region to the shell during vigorous movement of the foot. Another, sometimes rather deep muscle scars correspond in protobranchs to the visceral attachment muscles holding the muscular floor of visceral sac.

\section{Palaeoecology}

Using the known functional morphology of the shell in the Recent bivalves makes possible to interpret modes of life in the majority of fossil bivalves, and thus their palaeoenvironment. Bivalve living habit is divided into broad categories, each containing adaptive groups with certain unique morphologic features. Fang (2006) concluded that Cambrian bivalves were benthic crawlers and that infaunal mode of life in the bivalves is known from the Ordovician. Most part of the Ordovician bivalves is infaunal deposit feeders and filter feeders. Semi-infaunal and epifaunal elements are more abundant in the Late Ordovician. It corresponds also with studies of the Ordovician bivalves from Bohemia where in the Middle Ordovician Śárka Formation dominate heterodonts (infaunal filter feeders) and protobranchs (infaunal deposit feeders), possibly semi-infaunal bivalves like Modiolopsis and Cyrtodonta are very rare.

The palaeoecology of Pseudocyrtodonta was described in detail in Steinová (2012), Pseudocyrtodonta was most probably an active infaunal burrower.

Redonia, Coxiconchia and Babinka were considered by Babin \& Gutiérrez-Marco (1991) as infaunal filter feeders. Typical character for Redonia is myophoric buttress on the anterior adductor muscle scar, which is developed in burrowers. The shell of Redonia is also often preserved with conjoined valves, which also supports the opinion that Redonia was infaunal burrower. Coxiconchia and Babinka belong with uncertainty to the Lucinidia (see discussion in Babinka prima). Recent Lucinidia are filter feeders and they live in symbiosis with chemosymbiotic bacteria (Reid 1990). Many lucinids burrow deeply, most of them live vertically in the sediment with hinge uppermost and they can survive in anaerobic zone. Distinctly elongated anterior adductor muscle scar in recent lucinids is an adaption for chemosymbiosis. Coxiconchia and Babinka show very similar hinge to recent lucinids, but the anterior and posterior adductor muscle scars have almost the same size. Both Coxiconchia and Babinka have the accessory muscle scars under the umbo; they are interpreted as impressions of visceral attachment and pedal muscle scars (Heath 1937, Bradshaw 1978, Liljedahl 1994 and Babin \& Farjat 1994, Kř́ž 1995). According to the degree of obesity (height/width ratio) Babinka and Coxiconchia were rapid burrowers. From the shape of Babinka, which is nearly circular in the lateral view, it is possible to conclude that they penetrated vertically downwards.

Modiolopsis and Cyrtodonta are considered as endobyssate filter feeders even when the internal morphology of Modiolopsis and Cyrtodonta is not well known and other research is necessary.

Praenucula and Concavodonta are very probably infaunal deposit feeders, often preserved with conjoined valves or sometimes as the opened shell (Figs 2L, 4P, R).

Tatula was probably an infaunal filter feeder, like others actinodonts.

\section{Fossil associations of the Šárka Formation}

Diversified fauna from the Šárka Formation was studied by many authors almost two hundred years, but mainly Havlíček \& Vaněk (1966, 1990), Havlíček (1982), Havlíček 
(1998), Mikuláš (1991), Mergl (2002), Mergl et al. (2008), Budil et al. (2007), Lefebvre (2007), Fatka \& Mergl (2009) determined its invertebrate communities. Havlíček (1982) established Placoparia Community, which was redefined as the Euorthisina-Placoparia Community by Havlíček \& Vaněk (1990). Vavrdová (1982) studied phytoplankton communities. Mikuláš (1991) recognized ichnofossil assemblages, which he assigned to the Cruziana and Zoophycos ichnofacies and Mergl (2002) described Rafanoglossa Community within his Paterula Community Group. Budil et al. (2003a, b), Fatka (2003), Chlupáč (2003), Kraft et al. (2003), Kraft \& Kraft (2003) and Mikuláš (2003) described faunal association from Prague - Červený vrch Hill, where the phyllocarids and graptolites dominated. Lefebvre (2007) distinguished two biofacies based on echinoderms; mitrocystitid biofacies in the shallower western part of the Prague Basin and lagynocystid biofacies in the deeper eastern part of the Prague Basin. Budil et al. (2007) discussed mainly trilobite associations and briefly described merostomes, phyllocarids, brachiopods, echinoderms, arcitarchs, chitinozoans and graptoloids.

Generally molluscs have been a neglected group and the complex data from the Middle Ordovician bivalves of Bohemia have not been published. During this revision of the Middle Ordovician bivalves I counted and determined all specimens and then statistically analysed the data using the methodology of Kř́ž (1999). This analysis is based on the specimens deposited in the collections of the National Museum, Prague, Museum of Dr. Bohuslav Horák, Rokycany, which were built especially by J. Barrande, F. Hanuš, K. Holub and J. and P. Kraft, in the private collection of Vladislav Kozák, and in my own collection deposited in the Czech Geological Survey.

\section{Euorthisina-Placoparia Association}

Name. - Used for the first time by Havlíček \& Vaněk (1990).

Age. - Šárka Formation, early and middle Darriwilian.

Type locality. - Osek near Rokycany, Bohemia.

Geographic distribution. - Prague Basin, Bohemia.

Composition. - The abundant brachiopods show relatively low diversity, dominated by genera Eodalmanella Havlíček, 1950 and Euorthisina Havlíček, 1950. The trilobites are significant group with various ecological types (particle feeders, filter feeders, scavengers, predators possible large predators, pelagic and nektic elements, possible epiplankton and plankton, Budil et al. 2007). Very abundant are gastropods, univalved molluscs (Tropidodiscus Meek
\& Worthen, 1866, Gamadiscus Horný, 1962, Sinuites Koken, 1896, Mourlonia de Koninck, 1883, Lesuerella Koken, 1896) and bivalves, where actinodonts and protobranchs dominate (Redonia, Pseudocyrtodonta, Praenucula, Concavodonta). The other frequent groups are hyolithids (Gompholites Marek, 1966, Elengatilites Marek, 1966, Pauxillites Marek, 1966, Bactrotheca Novák, 1891) and benthic ostracods (Dilobella Ulrich, 1894, Cerninella Přibyl, 1966, Conchoprimites Hessland, 1949). Highly diversified echinoderm fauna includes fourteen species, of which stylophoran taxa are dominant. Cephalopods represent mainly demersal predators (ellesmerocerids, endocerids, pseudoortocerids) and planktic orthocerids (Manda 2008a). Phyllocarids are widespread, but monotonous Caryocaris. Merostomes are represented by one rare species.

Environment. - The richly diversified fauna, which is assigned to Euorthisina-Placoparia Association was mostly gathered from the loose siliceous nodules. This fauna is preserved also in the shales, but the preservation is worse than in the siliceous nodules. According to Kukal (1962) these nodules were primarily carbonate and then they were subsequently silicified. Havlíček et al. (1994) considered bivalves in Euorthisina-Placoparia Association as vagile benthos. Kř́ž (1997) briefly described composition, general diversity, and modes of life in the Ordovician bivalve associations. He pointed out that the environment of unconsolidated dark clay to silty muds rich in organic matrix of the Śárka Formation was most favourable for infaunal deposit-feeders, especially protobranchs. Havlíček (1998) mentioned that infaunal elements are rare, but the bivalve association described here (Table 1, Fig. 14, 15) is quite diversified (12 species of bivalves) and abundant (1524 specimens collected during almost two hundred years). The bivalves are well preserved, mostly as the shells with conjoined valves $(61.1 \%)$. In the subtidal, soft bottom environment the abundant infaunal deposit-feeding bivalves (Praenucula) occur $(35.5 \%)$. The dominance of actinodonts (infaunal filter feeders $56.4 \%$ ) could be partially artificial, because of Redonia. Fossiliferous nodules attracted attention of a lot of private collectors, who were focused mainly on trilobites and small bivalves were very often overlooked. Redonia is one of the large bivalves in the Śarka Formation and therefore it is more probable that it was more readily noticed and preferentially collected. In most of the bivalve species of the Śarka Formation the number of the articulated specimens is about $50 \%$ or more, but Babinka is represented by only $13 \%$ of the articulated specimens. It seems that $B a-$ binka was very shallow infaunal filter feeder.

Most of the bivalves are common to both parts of the Prague Basin (the eastern part - Prague area, and the western part-Rokycany area). The exceptions are Coxiconchia occuring only in the Rokycany area and Cyrtodonta, Modiolopsis and Tatula occuring only in the Prague area. 
Table 1. Numerical and ranked abundance of bivalves from the old collections of bivalves in the Euorthisina-Placoparia Association, Šra Formation, early and middle Darriwilian, Middle Ordovician of Bohemia. RV and LV - right and left valves (disarticulated); A - shells with conjoined valves; RA - percentage relative abundance; AA - percentage relative abundance of shells with conjoined valves; $\mathrm{R}$ - ranked abundance.

\begin{tabular}{llrrrrrr}
\hline Species & $\begin{array}{l}\text { Life } \\
\text { habits }\end{array}$ & RV & LV & A & RA & AA & R \\
\hline Redonia deshayesi & infaunal & 154 & 181 & 286 & 41.3 & 63.1 & 1 \\
Praenucula bohemica & infaunal & 31 & 45 & 106 & 13.10 & 73.6 & 2 \\
Praenucula applanans & infaunal & 39 & 46 & 87 & 11.80 & 67.28 & 3 \\
Praenucula dispar & infaunal & 48 & 49 & 65 & 10.30 & 57.2 & 4 \\
Pseudocyrtodonta incola & infaunal & 40 & 28 & 65 & 9.00 & 65.7 & 5 \\
Pseudocyrtodonta ala & infaunal & 38 & 23 & 33 & 5.80 & 52 & 6 \\
Babinka prima & infaunal & 45 & 62 & 8 & 5.60 & 13 & 7 \\
Coxiconchia britannica & infaunal & 2 & 2 & 12 & 1.30 & 85.7 & 8 \\
Modiolopsis sp. & infaunal & 8 & 7 & 6 & 1.20 & 44.4 & 9 \\
Concavodonta ponderata & infaunal & 2 & 2 & 1 & 0.30 & 33.3 & 10 \\
Tatula petula & infaunal & - & 1 & 2 & 0.20 & 80 & 11 \\
Cyrtodonta sp. & infaunal & - & 1 & - & 0.05 & - & 12 \\
Totals & & 407 & 446 & 671 & $99.95 \%$ & $61.10 \%$ & \\
\hline
\end{tabular}

This bivalve fauna has some elements in common ( $\mathrm{Ba}$ binka, Coxiconchia, Redonia, Modolopsis, Cyrtodonta) with the older faunas of the Montagne Noire, France and Wales (Babin 1982 in Babin et al. 1982, Cope 1996). According to Havlíček et al. (1994) Havlíček (1998) and Fatka \& Mergl (2009) this similarity could indicate easy migration of mobile benthic larvae along deep shelves and between separate terranes (Avalonia, Armorica, Perunica and cratonic West Gondwana). According to Cope (2002) the Early and Middle Ordovician bivalves were already highly diversified and abundant group in many regions (collections from Montagne Noire - 249 specimens and nine species, South Wales - 1271 specimens and twenty species, mid-Wales - 490 specimens and thirteen species, Spain 2419 specimens and fifteen species, Australia - 523 specimens and thirty species). In South Wales the bivalves even dominated the early Ordovician fauna from the Llangynog Inlier (Cope 1996). From France are described Middle Ordovician bivalve shell beds with dominant Redonia and Praenucula (Babin 1966, Dabard et al. 2007). The other bivalve shell beds are known from North America, the dominant element is Modiolopsis (Li \& Droser 1999).

\section{Diversification and paleobiogeography of bivalves during the Middle Ordovician}

Ordovician diversification and palaeobiogeography of the bivalves was intensively studied by Babin (1993a, b, 1995, 2000), Cope (2002, 2004), Cope \& Babin (1999), Sánchez

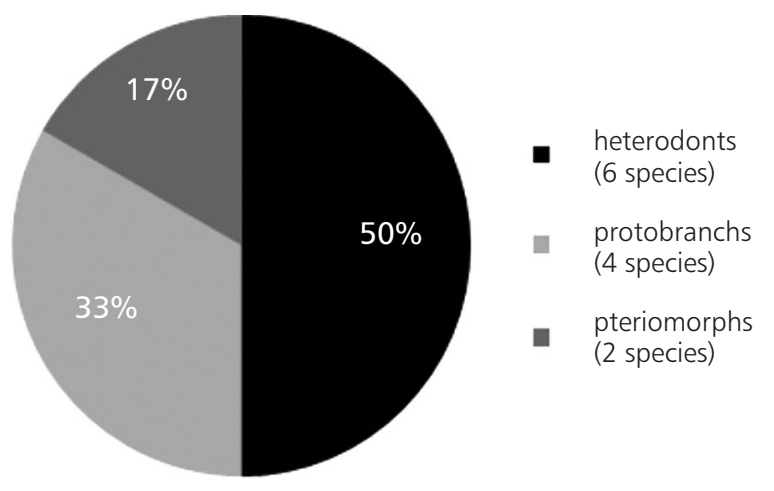

Figure 14. The species composition and diversity of the bivalve fauna from the Middle Ordovician Śárka Formation.

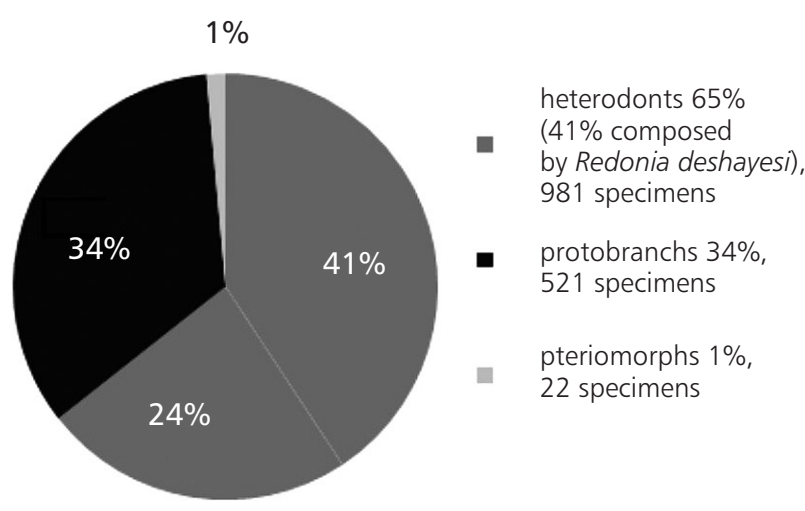

Figure 15. Abundance of bivalve individuals composing collections of the bivalve fauna from the Middle Ordovician Śárka Formation, according to Table 1 .

(2008), Sánchez \& Babin (2003) and Fang (2006). The Ordovician was the most significant period in bivalve diversification. Early Ordovician bivalves were restricted to periGondwanan shelves and favoured inshore clastic sedimentary environments. During the Middle Ordovician the bivalves were able to migrate to other continents, but initially remained largely confined to nearshore clastic facies (Cope $\&$ Babin 1999). In the Late Ordovician the widespread occurrence of low-latitude carbonate platforms provided an ideal habitat for epifaunal bivalves and they became a very diverse class, adapted to many modes of life (Cope \& Babin 1999).

Cope (2002) compared the Ordovician bivalves from high, median and low latitudes and revealed difference in both, bivalve diversity and faunal composition. The number of species at equatorial latitudes is twice that of the highest latitude. There was clear preference of the pteriomorphs for low latitudes and heterodonts for high latitudes. The conclusion of Cope (2002) is also confirmed by the composition of the Middle Ordovician Šarka Formation bivalve fauna from Bohemia where heterodonts prevail with six species (Fig. 14) and 981 specimens (Fig. 15, Table 1). 


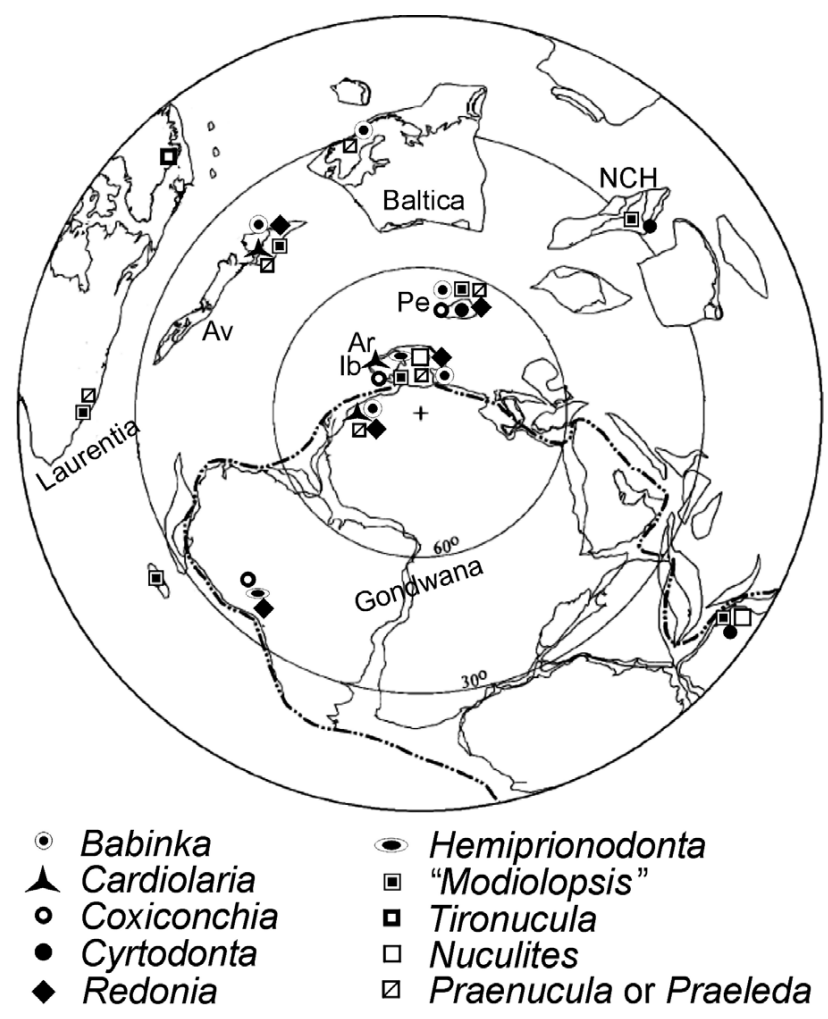

Figure 16. Palaeogeographic distribution of the bivalves during the Middle Ordovician, palaeogeographic map according to Cocks \& Torsvik (2002). Abbreviations: Ar - Armorica, Av - Avalonia, Ib - Iberia, $\mathrm{NCH}$ - North China, Pe - Perunica.

Sánchez \& Babin (2003) studied the palaeogeographical distribution of bivalves during the Ordovician and their suitability for palaeogeographical reconstruction. They concluded that bivalves are not relevant palaeobiogeographic indicators, because of the low percentage of shared genera among different localities (80\% from 144 known genera are locally endemic). According to Cope \& Kř́iž (2013) the number of the Ordovician genera increased during research history and today almost 170 genera of Ordovician bivalves are known. The possibility of colonising different areas depends on different factors: abiotic and biotic. The abiotic factors include the distance between the regions, the position of the geographic barriers, the directions and speed of the sea currents and the living conditions in the surroundings, which could be colonised. The biotic factors mainly include available ecospace, the competition between species and the characters of the species. Sánchez \& Babin (2003) suggest that Ordovician bivalves were very probably stenotopic and their occurrence was controlled by the living conditions characteristic for each basin. Probably the taphonomic conditions are not the limiting factor for the record of the Ordovician bivalves, because other molluscs with aragonitic shells are abundant in strata where the bivalves are very rare or absent.
The other aspect, which is very important for the distribution of the Ordovician molluscs, is the larval type. According to Thorson (1961) or Jablonski \& Lutz (1980) about 65-70\% the Recent species of bivalves have planktotrophic larvae and this type of larva permits the dispersion over the large distances. Babin (1995) and Sánchez \& Babin (2003) presumed that all the Ordovician bivalves had the lecithotrophic larvae and this could explain the spatial restriction for the Ordovician bivalve genera (for early ontogenetic strategies in other molluscs, see Nützel \& Frýda 2003, Manda 2008b, Klug et al. 2010, Manda \& Frýda 2010, Laptikhovsky et al. 2013). Thorson (1961) studied the length of pelagic larval life in Recent marine invertebrates (including bivalves) and the larval transport by ocean currents. Recent surface currents of average velocity can transport bivalves, with a pelagic larval life span of about 6 weeks, in one generation for a distance of 900-1,500 km.

The palaeogeographic distribution of the Middle Ordovician bivalves is shown on Fig. 16, for better clarity was chosen the genera, which are recorded in the three or more regions. Tironucula Morris \& Fortey, 1976 is the exception, because Middle Ordovician bivalves from the North America are rare and it is important to mention all the bivalves, which occur there. The genus Ctenodonta was excluded from this analysis, because under this generic name was assigned many bivalves with different shape and hinge. After the revision of bivalve fauna in the peri-Gondwana and Gondwana region, many species, which belonged to Ctenodonta, were reassigned to Praenucula or Praeleda. Praenucula and Modiolopsis are also somewhat problematic (see discussion above about these genera) and therefore I prefer the designation Praenucula or Praeleda and "Modiolopsis". Despite this problem with taxonomy, Middle Ordovician bivalves often went through modern revision and therefore their data are the most complex. Sánchez \& Babin (2003, table 2) mentioned that no endemic genera are in Bohemia, but after the revision it is obvious that two genera (Pseudocyrtodonta and Tatula) are recorded only from Bohemia. The Middle Ordovician bivalves remain confined to the Gondwana and peri-Gondwana regions (including Avalonia and North China). But some of the Middle Ordovician genera could overcome long distances. Modiolopsis is recorded from Australia, Bohemia (Perunica), Spain (Iberia), Wales (Avalonia), Argentina (Argentine Precordillera), North China, and North America. Babinka is known from Morocco, Spain, France, Bohemia, Sweden (Baltica) and Wales. Coxiconchia is recorded from Bohemia, Spain, France and Bolivia. Praenucula or Praeleda are known from Bohemia, England, France, Iberia, Morocco, Sweden, Wales and probably North America. It seems that some of the Middle Ordovician genera had to have planktotrophic larvae and therefore they could be widely dispersed not only around the Gondwana but they could reach the margins of 
Laurentia and Baltica. But it is only in the Late Ordovician that oceanic barriers had narrowed sufficiently for bivalves to become cosmopolitan again, for the first time since the Mid Cambrian (Cope \& Kř́̌ž 2013). For the distribution of the Silurian bivalves the temperature, salinity, substrate, food, oxygen content, light, and depth were more limiting factors than geographical barriers, as was the distance between favourable environments. Silurian protobranchs are widely distributed, known from the regions close to equator (Baltica, Laurentia and Gondwana) but also from the regions distant from Silurian equatorial latitudes as South American Gondwana (Cope \& Křiž 2013).

Middle Ordovician bivalve fauna from Bohemia (Perunica) shows close affinities to the Middle Ordovician fauna known from Spain (Iberia) and France (Armorica) (Fig. 16). Four species (C. britannica, R. deshayesi, P. applanans, B. prima) are in common with Spain and three species ( $C$. britannica, $R$. deshayesi and B. prima) with France. The occurrence of $C$. britannica, $R$. deshayesi and B. prima in Bohemia is related to better sea communication between Perunica (Prague Basin) and other periGondwana regions where they occurred earlier.

\section{Conclusions}

(i) Ctenodonta was widely used in the past as a cumulative name for all praenuculids. The genus Ctenodonta Salter, 1852 does not occur in the Middle Ordovician of Bohemia and very probably does not occur in whole Ordovician in the Prague Basin. All the species from the Middle Ordovician of Bohemia assigned in the past to Ctenodonta belong to Praenucula.

(ii) Actinodonts are dominant group of bivalves in the Middle Ordovician. A new genus Tatula gen. nov. with the new type of actinodont hinge is decribed herein.

(iii) The oldest representatives of pteriomorphans (Modiolopsis sp. and Cyrtodonta sp.) in the Prague Basin are described here.

(iv) The value of the orientation of teeth to umbo or out from the umbo for higher systematic of the Protobranchia is probably overestimated. The Recent Protobranchia mostly shows simpler types of taxodont teeth compared with the Ordovician Protobranchia. The accessory muscle scars serve in the Protobranchia to hold visceral sac and also support retraction, protraction and elevation of foot together with the protractor and retractor pedal muscle scars.

(v) The bivalve fauna from the Šárka Formation is diversified (12 species) and abundant (1524 specimens known in the Bohemian collections) and it forms part of the Euorthisina-Placoparia Association. Bivalves represent infaunal deposit and filter feeders, endobyssate filter feeders are rare and they are firstly recorded from the Middle Ordovician of Bohemia. (vi) Clear preference of the heterodonts for high latitudes (Cope 2002) is confirmed by the dominant heterodonts (six species) in the Middle Ordovician Šarka Formation.

(vii) The palaeogeographic distribution of the Middle Ordovician bivalves is presented. During the Ordovician about $80 \%$ known genera of bivalves were locally endemic. On the other hand it was observed that some of the Middle Ordovician bivalves (Babinka, Modiolopsis, Praenucula) could migrate over long distances, when they reach Baltica and Laurentian margins and thus had to have planktotrophic larvae. Bivalve fauna of Bohemia shows the most elements in common with France (Armorican Massif) and Spain (Iberian Peninsula).

\section{Acknowledgements}

I am indebted to Jiří Kř́ž from the Czech Geological Survey, Prague for his permanent help and to John Cope, National Museum of Wales for helpful improvement of the English and constructive comments that very improve this manuscript. Many thanks belong to Vladislav Kozák, who kindly provided his private collection of bivalves for my research. I would like to express many thanks to Muriel Vidal from the University of Western Brittany in Brest and Juan Carlos Gutiérrez-Marco from the Complutense University in Madrid, who kindly provided access to the collections and presented me fields in France and Spain. Many thanks belong to Virginie Héros from the Museum of Natural History in Paris and to John Pojeta from the Smithsonian Institution in Washington D.C. who presented me the collections of the Recent bivalves. Many thanks belong to Vojtěch Turek and Martin Valent from the National Museum and Martina Korandová from the Museum of Dr. Bohuslav Horák in Rokycany, who kindly provided access to their collections. Also I would like to thank John Pojeta, Claude Babin, John Cope, Petr Budil, Olda Fatka, Štěpán Manda and Petr Kraft for many valuable suggestions. The research was funded by GA ČR (Czech Science Foundation) 205/09/1521, by the Czech Geological Survey in the project 334600, by Sepkoski grant and by the French Government project. This article is also contribution to the IGCP project 591.

\section{References}

BABIN, C. 1966. Mollusques Bivalves et Céphalopodes du Paléozoïque armoricain. 470 pp. Imprimerie Commerciale et Administrative, Brest.

BABIN, C. 1977. Étude comparée des genres Babinka Barrande et Coxiconchia Babin (Mollusques Bivalves de l'Ordovicien) intérêt phylogénétique. Géobios 10(1), 51-79.

DOI 10.1016/S0016-6995(77)80054-5

BABIN, C. 1982. Mollusques bivalves et rostroconches, 37-49. In Babin, C., Courtessole, R., Melou, M., Pillet, J. \& Vizcaïno, D. Brachiopodes (articulés) et mollusques (bivalves, rostroconches, monoplacophores, gastropodes) de 
l'Ordovicien inférieur (Trémadocien-Arenigien) de la Montagne Noire (France méridionale). Mémoire de la Société des Études Scientifiques de l'Aude. 63 pp. Sival, Carcassonne.

BABIN, C. 1985. Pseudarca, Mollusques Bivalve singulier de l'Ordovicien supérieur du Massif Armoricain. Extrait des Annales de la Société géologique du Nord 105, 253-258.

BABIN, C. 1993a. Rôle des plates-formes gondwaniennes dans les diversification des mollusques bivalves durant l'Ordovicien. Bulletin de la Société géologique de France 164(2), 141-153.

BABIN, C. 1993b. La répartition géographique des mollusques bivalves du Palézoïque (Cambrien à Devonien): une revue. Palaeogeography, Palaeoclimatology, Palaeoecology 100, 7-20. DOI 10.1016/0031-0182(93)90027-G

BABIN, C. 1995. The initial Ordovician bivalve mollusc radiations on the Western Gondwanan shelves. In Coope, D., Droser, M.L. \& Finney, S.C. (eds) Ordovician Odyssey: Short papers, $7^{\text {th }}$ international Symposium on the Ordovician System. Book 77, Pacific section Society for Sedimentary Geology (SEPM).

BABIN, C. 2000. Ordovician to Devonian diversification of the Bivalvia. American Malacological Bulletin 15, 167-178.

Babin, C. \& Beaulieu, G. 2003. Les Mollusques Bivalves de l'Ordovicien de Saint-Clément-de-la-Place (Maine-et-Loire, sud-est du Massif Armoricain). Bulletin de la Société Scientifique Naturelle Ouest de la France, nouvelle série 25(4), 177-206.

Babin, C. \& Destombes, J. 1990. Les Mollusques Bivalves et Rostroconches ordoviciens de l'Anti-Atlas marocain: Intérêt paléogéographique de leur inventaire. Géologie Méditerranéenne 17(3-4), 243-261.

BABIN, C. \& FARJAT, A.D. 1994. Unsual accessory muscle scar patterns in two species of Palaeoneilo, a palaeotaxodont bivalve from Devonian of Bolivia. Journal of Paleontology 68(5), 1041-1047.

Babin, C. \& Gutiérrez-Marco, J.C. 1985. Un noveau Cycloconchidae (Mollusca Bivalvia) du Llanvirn inférieur (Ordovicien) des Monts de Tolede (Espagne). Geobios 18(5), 609-616. DOI 10.1016/S0016-6995(85)80060-7

Babin, C. \& GutiérRez-Marco, J.C. 1991. Middle Ordovician bivalves from Spain and their phyletic and palaeogeographic significance. Palaeontology 34(1), 109-147.

Babin, C. \& Melou, M. 1972. Mollusques Bivalves et Brachiopodes des "schistes de Raguenez" (Ordovicien supérieur du Finistère); conséquences stratigraphiques et paléobiogéographiques. Annales de la Société Géologique du Nord 92(2), 79-94.

Babin, C. \& Robardet, M. 1973. Quelques Paleotaxodontes (Mollusques Bivalves) de l'Ordovicien supérieur de SaintNicolas-de-Pierrepont (Normandie). Bulletin de la Société géologique et minéralogique de Bretagne 4(1), 25-38.

BAILEY, J.B. 2009. Shell orientation morphology among the Bivalvia (Mollusca): Problems and proposed solution. Journal of Palaeontology 83(3), 493-495. DOI 10.1666/08-111.1

BARRANDE, J. 1846. Notice préliminaire sur le systême silurien et les trilobites de Bohême. 97 pp. Hirschfeld, Leipzig.

Barrande, J. 1881. Systême silurien du centre de la Bohême. Classe des Mollusques, ordre des Acéphalés 6. 342 pp. Privately published, Prague $\&$ Paris.

BARRoIs, C. 1891. Mémoire sur la faune du Grès armoricain. Annales de la Société géologique du Nord 19, 134-237.
Bellardi, L. 1875. Monografia delle Nuculidi trovate finora nei terreniterziari del Piemonte e della Liguria. 28 pp. Tipografia Eredi Botta, Torino.

Bergström, S.M., Chen, X., Gutiérrez-Marco, J.C. \& Dronov, A. 2008. The new chronostratigraphic classification of the Ordovician System and its relations to major regional series and stages and to $\delta^{13} \mathrm{C}$ chemostratigraphy. Lethaia 42(1), 97-107. DOI 10.1111/j.1502-3931.2008.00136.x

Beurlen, K. 1944. Beiträge zur Stammesgeschichte der Muscheln. Mathematisch-Naturwissenschaftlichen Abteilung der Bayerischen Akademie der Wissenschaften zu München, Sitzungsberichte 1944(1-2), 133-145.

Bigot, A. 1889. Notes sur quelque Pélécypodes des grès siluriens de l'ouest de la France. Bulletin de la Société géologique de France 17, 791-801.

BiLlings, E. 1858. On the Asteridae of the Lower Silurian rocks of Canada. Figures and descriptions of Canadian organic remains. Geological Survey of Canada 3, 75-85.

BiLlings, E. 1874. Palaeozoic fossils. Geological Survey of Canada 2(1). 144 pp. Dawson Brothers, Montreal.

Born, A. 1918. Die Calymene tristani = Stufe (mittleres Untersilur) bel Almaden, Ibre Fauna, Gliederung und Verbreitung. Senckenbergische Naturforschende Gesellschaft, Abhandlungen 36(3), 309-358.

BouČEK, B. 1927. Příspěvek ke stratigrafii vrstev šáreckých $\mathrm{d}_{\gamma}$ českého ordoviku. Rozpravy České akademie věd a umění, Třída II, 37, 33.

BouČEK, B. 1973. Lower Ordovician graptolites of Bohemia. 185 pp. Academia, Praha.

Bradshaw, M.A. 1970. The dentition and musculature of some Middle Ordovician (Llandeilo) Bivalves from Finistère, France. Palaeontology 13(4), 623-645.

Bradshaw, M.A. 1978. Position of soft part in fossil palaeotaxodont bivalves as suggested by features of the shell interior. Alcheringa 2, 203-215.

DOI 10.1080/03115517808527777

Bradshaw, M.A. \& Bradshaw, J.D. 1971. Functional morphology of some fossil palaeotaxodont bivalve hinges as a guide to orientation. Palaeontology 14(2), 242-249.

Budil, P., Chlupáč, I. \& Hradecký, P. 2003. Middle Ordovician at Praha - Červený vrch Hill (Barrandian area, Czech Republic). Bulletin of Geosciences 78(2), 91-98.

Budil, P., FatKa, O. \& Bruthansová, J. 2003. Trilobite fauna of the Šárka Formation at Praha - Červený vrch Hill (Ordovician, Barrandian area, Czech Republic). Bulletin of Geosciences 78(2), 113-117.

Budil, P., Fatka, O., Kolár̆, P. \& David, M. 2011. Arthrorhachis Hawle \& Corda, 1847 (Agnostida) in the Prague Basin (Barrandian area, Czech Republic) revisited. Bulletin of Geosciences 86(4), 707-724. DOI 10.3140/bull.geosci.1262

Budil, P., Kraft, P., Kraft, J. \& FAtKA, O. 2007. Faunal associations of the Šarka Formation (Middle Ordovician, Darriwilian, Prague Basin, Czech Republic). Acta Palaeontologica Sinica, Supplement 46, 64-70.

Carter, J.G., Altaba, C.R., Anderson, L.C., Araujo, R., Biakov, A.S., Bogan, A.E., Campbell, D.C., Campbell, M., Chen, J., Cope, J.C.W., Delvene, G., Dijkstra, H.H., FAng, Z., GardNer, R.N., Gavrilova, V.A., Goncharova, I.A., Harries, P.J., Hartman, J.H., Hautmann, M., Hoen, W.R., Hylleberg, J., 
Jiang, B., Johnston, P., Kirkendale, L., Kleemann, K., KoppKa, J., KŘíž, J., Machado, D., Malchus, N., MárquezAliaga, A., Masse, J.-P., Mc Roberts, C.A., Middelfart, P.U., Mitchell, S., Nevesskaya, L.A., Özer, S., Pojeta, J. JR., Polubotko, I.V., Pons, J.M., Popov, S., Sánchez, T., SARtori, A.F., Scott, R.W., Sey, I.I., Signorelli, J.H., Silantiev, V.V., Skelton, P.W., Steuber, T., Waterhouse, J.B., Wingard, G.L. \& YANCEY, T. 2011. A synoptical classification of the Bivalvia (Mollusca). University of Kansas, Paleontological Institute, Paleontological Contributions 4, 1-47.

Carter, J.G., Campbell, D.C. \& CampBell, M.R. 2000. Cladistic perspectives on early bivalve evolution, 47-79. In HARPER, E.M., TAYLOR, J.D. \& CRAME, J.A. (eds) The evolutionary biology of the Bivalvia. Geological Society of London, Special Publication 177.

Carter, J.G., Harries, P.J., Malchus, N., Sartori, A., AnderSon, L.C., Bieler, R., Bogan, A.E., CoAn, E.V., Cope, J.C.W., Cragg, S.M., Garcia-March, J.R., Hylleberg, J., Kelley, P., Kleeman, K., Kříž, J., McRoberts, C., Mikkelsen, P.M., Pojeta, J., Temkin, I., Yancey, T. \& ZieritZ, A. 2012. Illustrated glossary of the Bivalvia. Treatise Online No. 48: Part N, Vol. 1, Mollusca 6, Bivalvia. Paleontological Institute, University of Kansas.

CHLUPÁČ, I. 2003. Phyllocarid crustaceans from the Middle Ordovician Šárka Formation at Praha-Vokovice. Bulletin of Geosciences 78(2), 107-111.

Cocks, L.R.M. \& ToRsviK, T.H. 2002. Earth geography from 500 to 400 million years ago: a faunal and palaeomagnetic review. Journal of the Geological Society of London 159, 631-644. DOI 10.1144/0016-764901-118

ConRAD, T.A. 1838. Report on the palaeontological department of the survey (of New York). New York Geological Survey Annual Report 2, 107-119.

Cope, J.C.W. 1996. Early Ordovician (Arenig) bivalves from the Llangynog Inlier, South Wales. Palaeontology 39(4), 979-1025.

Cope, J.C.W. 1997. The early phylogeny of the class Bivalvia. Palaeontology 40(3), 713-746.

Cope, J.C.W. 1999. Midle Ordovician bivalves from Mid-Wales and the Welsh Borderland. Palaeontology 42(3), 467-499. DOI 10.1111/1475-4983.00081

Cope, J.C.W. 2002. Diversification and biogeography of bivalves during the Ordovician Period, 25-52. In Crame, J.A. \& Owen, A.W. (eds) Palaeogeography and Biodiversity Change: the Ordovician and Mesozoic-Cenozoic Radiations. Geological Society of London, Special Publication 194.

COPE, J.C.W. 2004. Chapter 20. Bivalve and rostroconch molluscs, 196-208. In WebBy, B. D., PARIS, F., Droser, M.L. \& Percival, I.G. (eds) The great Ordovician biodiversification event. Columbia University Press, New York.

CoPE, J.C.W. \& BABIN, C. 1999. Diversification of bivalves in the Ordovician. Geobios 32(2), 175-185.

DOI 10.1016/S0016-6995(99)80029-1

Cope, J.C.W. \& KŘíž, J. 2013. The Lower Palaeozoic palaeobiogeography of Bivalvia. Geological Society of London, Memoir (in press).

DABARD, M.P., LoI, A. \& Paris, F. 2007. Relationship between phosphogenesis and sequence architecture: Sequence stratigraphy and biostratigraphy in the Middle Ordovician of the
Armorican Massif (NW France). Palaeogeography, Palaeoclimatology, Palaeoecology 248, 339-356.

DOI 10.1016/j.palaeo.2006.12.011

DaLL, W.H. 1889. On the hinge of pelecypods and its development, with an attempt toward a better subdivision of the group. American Journal of Science and Arts (series 3), 38(228), 445-462.

DALL, W.H. 1907. Description of new species of shells, chiefly Buccinidae, from the dredgings of the U.S.S. 'Albatross' during 1906, in the northwestern Pacific, Bering, Okhotsk, and Japanese Seas. Smithsonian Miscellanea Collection 50, $139-173$.

De Verneuil, E.P. \& Barrande, J. 1856. Description des fossiles trouvés dans les terrains siluriens et dévoniens d'Almaden, d'une partie de la Sierra Morena et des montagnes de Tolède. Bulletin de la Société Géologique de France 2(12), 964-1025.

Dechaseaux, C. 1952. Classes des Lamellibranches (Lamellibranchiata Blainville, 1816), 220-364. In Piveteau, J. (ed.) Traité de Paléontologie 2. Masson et Cie, Paris.

Delgado, J.F.N. 1908. Système silurique du Portugal. Étude de stratigraphie paléontologique. 245 pp. Memórias e Comunicaçoes dos Serviços Geológicos de Portugal, Lisboa.

Des Moulins, C. 1832. Description d'un genre nouveau de coquille vivante, Bivalve des mers du Chili. Actes de la Société Linéenne de Bordeaux 5(26), 1-10.

Douvillé, H. 1912. Classification des Lamellibranches. Bulletin de la Société géologique de France 12(1912), 419-467.

Driscoll, E.G. 1964. Accessory muscle scars, an aid to protobranch orientation. Journal of Palaeontology 38(1), 61-66.

Drost, K., Linnemann, U., Wemmer, K., Budil, P., Kraft, P., FAtKa, O. \& MAREK, J. 2003. Provenance and early diagenetic processes of the Ordovician Šárka Formation at Praha Červený vrch Hill (Barrandian, Czech Republic). Bulletin of Geosciences 78(2), 147-156.

FANG, Z.J. 2006. An introduction to Ordovician bivalves of southern China, with a discussion of the early evolution of the Bivalvia. Geological Journal 41, 303-328. DOI $10.1002 / \mathrm{gj} .1048$

FANG, Z.J. \& CoPE, J.C.W. 2004. Early Ordovician bivalves from Dali, West Yunnan, China. Palaeontology 47(5), 1121-1158. DOI 10.1111/j.0031-0239.2004.00403.x

FANG, Z.J. \& COPE, J.C.W. 2008. Affinities and palaeobiogeographical significance of some Ordovician bivalves from East Yunnan, China. Alcheringa 32, 297-312. DOI 10.1080/03115510802096150

FATKA, O. 2003. Organic-walled microfossils (Chitinozoa and Acritarcha) from the Praha - Červený vrch Hill (Šárka Formation, Middle Ordovician, Prague Basin). Bulletin of Geosciences 78(2), 119-127.

FAtKa, O., Lerosey-Aubril, R., Budil, P. \& RAK, Š. 2013. Fossilised guts in trilobites from the Upper Ordovician Letná Formation (Prague Basin, Czech Republic). Bulletin of Geosciences $88(1), 95-104$.

FatKa, O. \& Mergl, M. 2009. The "microcontinent" Perunica: status and story 15 years after conception, 65-102. In BASSETT, M.G. (ed.) Early Palaeozoic Peri-Gondwanan Terranes: New Insights from Tectonics and Biogeography. Geological Society of London, Special Publications 325.

Férussac, A.E.J. \& D'Audebard, D.E. 1821-1822. Tableaux 
Systèmatiques des Animaux Mollusques suivis d'un Prodrome Général pour tous les Mollusques Terrestres ou Fluviatiles Vivants ou Fossiles. Première Partie, Tableaux Systématiques Généraux. Arthus-Bertrand \& J.B. Sowerby, Paris \& London.

Fischer, P.H. 1886. Manuel de Conchyliologie et de Paléontologie Conchyliologique, ou Histoire Naturelle des Mollusques Vivants et Fossiles suivi d'un Appendice sur les Brachiopodes par D.P. Oehlert. Avec 23 planches contenant 600 figures dessinées par S. P. Woodward. Fasc. 10, pp. 897-1008 [April 30; 1886]. Published in 11 parts (fascicules), xxiv + 1369 pp. F. Savy, Paris.

Fuchs, A. 1919. Beitrag zur Kenntnis der Devon Fauna der Verse und Hobräcker Schichten des sauerländischen Faciesgebietes. Jahrbuch der Preussischen geologischen Landesanstalt 39(für 1918), 58-95.

Gigout, M. 1951. Études géologiques sur la Méséta marocaine occidentale. Notes et Mémoires du Service Géologique du Maroc 86, 1-507.

Giribet, G. 2008. Bivalvia, 105-141. In Ponder, W.F. \& LindBERG, D.R. Phylogeny and Evolution of the Mollusca. University of California Press, Berkeley.

Giribet, G. \& Distel, D.L. 2003. Bivalve phylogeny and molecular data, 45-90. In LydEARD, C. \& LindBERG, D.R. (eds) Molecular Systematics and Phylogeography of Mollusks. Smithsonian Books, Washington, D.C.

Gouzien, V. 1934. Contribution à l'étude géologique de la presqu'ile de Crozon suivant la voie ferrée de Telgruc à Camaret. Bulletin de la Société géologique et minéralogique de Bretagne 1930, 176-191.

GRAY, J.E. 1824. A supplement to the Appendix of Captain Perry's voyage for the discovery of a North West Passage, in the years 1819-1820, containing an account of the subjects of natural history, ccxl-ccxlvi. In PARRY, E.W. (ed.) Journal of a Second Voyage for the Discovery of a Northwest Passage from the Atlantic to the Pacific, Performed in the Years 1821-22-23, in His Majesty's Ships Fury and Hecla, under the Orders of Captain William Edward Parry, R. N., F. R. S. Appendix X. Natural History, Shells. J. Murray, London.

GRAY, J.E. 1854. A revision of the arrangement of the families of bivalve shells (Conchifera). The Annals and Magazine of Natural History (series 2) 13(77), 408-418.

GutiéRreZ-MArCo, J.C. \& BABIN, C. 1999. Lyrodesma et autres mollusques bivalves des Quartzites Botella (Ordovicien moyen) de la Zone Centre-Ibérique (Espagne). Revista Española de Paleontología, No. extr. (Homenaje al Prof. J. Truyols), 229-238.

Hall, J. 1847. Natural History of New York. Paleontology. Vol. 1. 338 pp. Geological Survey of New York.

Hanuš, F. 1923. Moje sbírka zkamenělin z českého Barrandienu. C̆asopis Národního muzea 97(2), 1-12, 73-84, 105-116.

HAVLíčEK, V. 1950. Ramenonožci českého ordoviku [The Ordovician Brachiopoda from Bohemia]. Rozpravy Ústředního ústavu geologického 13, 1-72.

HAVLíčEK, V. 1961. Rhynchonelloidea des böhmischen älteren Paläozoikums (Brachiopoda). Rozpravy Ústředního ústavu geologického 27, 1-211.

HAVlíčEK, V. 1967. Brachiopoda of the suborder Strophomenidina in Czechoslovakia. Rozpravy Ústředního ústavu geologického 33, 1-235.
HavlíčEK, V. 1980. Development of Palaeozoic basins in the Bohemian Massif (Cambrian-Lower Carboniferous). Sborník geologických věd, Geologie 34, 31-65.

HAVLIČEK, V. 1981. Development of a linear sedimentary depression exemplified by the Prague Basin (Ordovician-Middle Devonian; Barrandian area, Central Bohemia. Sborník geologických věd, Geologie 35, 7-48.

HavlíčEK, V. 1982. Ordovician in Bohemia: development of the Prague Basin and its benthic communitites. Sborník geologických věd, Geologie 37, 103-136.

Havlíček, V. 1998. Ordovician, 41-79. In Chlupáč, I., HavlíČEK, V., KŘíž, J., Kukal, Z. \& ŠToRCh, P. Paleozoic of the Barrandian (Cambrian to Devonian). 183 pp. Český geologický ústav, Praha.

HavlíčEK, V. \& FAtKa, O. 1992. Ordovician of the Prague Basin (Barrandian area, Czechoslovakia), 461-472. In WebBy, B. \& LAURIE, J. (eds) Global perspectives on Ordovician geology. Balkema, Rotterdam.

HAVLIČEK, V. \& VANĚK, J. 1966. The biostratigraphy of the Ordovician of Bohemia. Sborník geologických věd, Paleontologie 8, 7-69.

HAVLíčEK, V. \& VANĚK, J. 1990. Ordovician invertebrate communities in black shale lithofacies (Prague Basin, Czechoslovakia). Věstník Ústředního ústavu geologického 65, 223-236.

Havlíček, V., VanĚK, J. \& FatKa, O. 1994. Perunica microcontinent in the Ordovician (its position within the Mediterranean Province, series division, benthic and pelagic associations). Sborník geologických věd, Geologie 46, 23-56.

Heath, H. 1937. The anatomy of protobranch mollusks. Mémoires du Musée Royal d'Histoire Naturelle de Belgique, Série 2, 10, 1-26.

Hertwig, R. 1895. Lehrbuch der Zoologie, $3^{\text {rd }}$ edition. xii +599 pp. Gustav Fischer, Jena.

Hessland, I. 1949. Investigation of the Lower Ordovician of the Siljan District, Sweden, 11. Lower Ordovician penetrative and enveloping algae from the Siljan District. Bulletin of the Geological Institutions of the University Uppsala, 33, 409-429.

HoRnÝ, R. 1960. On the phylogeny of the earliest pelecypods (Mollusca). Věstník Ústředního ústavu geologického 35, 479-482.

HoRnÝ, R.J. 1962. New genera of Bohemian lower Paleozoic Bellerophontina. Věstník Ústředního ústavu geologického 37(5), 473-476.

JABLONSKI, D. \& LUTZ, R.A. 1980. Molluscan larval shell morphology. Ecological and paleontological applications, 323-377. In RhoAds, D.C. \& LuTz, R.A. (eds) Skeletal Growth of Aquatic Organisms. Chapter 9. Plenum Publishing, New York.

KettNer, R. \& Kodym, O. 1919. Nová stratigrafie Barrandienu (New stratigraphy of the Barrandian). Časopis Musea Království českého 93, 47-55.

Kettner, R. \& PrantL, F. 1948. Nové rozdělení a návrh jednotného značení vrstev středočeského ordoviku. Věstník Ústředního ústavu geologického 23, 49-68.

KLOUČEK, C. 1909. Předběžná zpráva o dvou různých horizontech v pásmu D1. Věstník Královské české společnosti nauk, Třída matematicko-př́rodovědná 1908(20), 1-4.

KLOUČEK, C. 1916. O vrstvách $d_{1 \gamma}$, jich trilobitech a nalezištích. Př́spěvek ke stratigrafii vrstev šáreckých $\mathrm{d}_{\gamma}$ českého ordoviku. Rozpravy České akademie věd a umění, Třída II 25(39), 1-20. 
Klug, C., Kröger, B., Kiessling, W., Mullins, G.L., Servais, T., FrÝdA, J., Korn, D. \& Turner, S. 2010. The Devonian nekton revolution. Lethaia 43, 465-477. DOI 10.1111/j.1502-3931.2009.00206.x

KoKEN, E. 1896. Ueber untersilurische Gastropoden. Neues Jahrbuch für Mineralogie, Geologie und Paleontologie 1, 1-25.

Koninck, L.G. De 1883. Faune du calcaire carbonifère de la Belgique, 4e partie, Gastéropodes (suite en fin). Musée Royale d'Historie Naturelle Belgique Annales, Série Paléontologique $8,1-240$.

KRAFT, J. 1974. Příspěvek k poznání graptolitové fauny klabavských vrstev (arenig) barrandienského ordoviku (I. - lokality Mýto a Volduchy) [On the graptolite fauna from the Klabava Formation (Arenig) of the Ordovician of the Barrandian (Part I - Mýto and Volduchy localities)]. Zprávy muzeí Západočeského kraje, Př́roda 16, 53-59.

Kraft, P., Budil, P., Chlupáč, I., FatKa, O., Kraft, J., Mikuláš, R., Mergl, M. \& Bruthansová, J. 2003. Fossil assemblages from the Middle Ordovician Šárka Formation at Praha - Červený vrch Hill (Prague Basin, Barrandian area). Bulletin of Geosciences 78(2), 99-101.

KRAFT, J. \& KRAFT, P. 1992. Biostratigraphy of the Klabava and Šárka Formations (Bohemia, Lower Ordovician) - a brief overview of new investigations. Acta Universitatis Carolinae, Geologica 1992(1-2), 23-29.

Kraft, J. \& KRAFT, P. 1993. The Arenig/Llanvirn boundary (Ordovician) in the Prague Basin (Bohemia). Journal of the Czech Geological Society 38(3-4), 189-192.

KRAFT, P. \& KRAFT, J. 2003. Middle Ordovician graptolite fauna from Praha - Červený vrch (Prague Basin, Czech Republic). Bulletin of Geosciences 78(2), 129-139.

Kraft, P., Kraft, J. \& Prokop, R.J. 2001. A possible hydroid from the Lower and Middle Ordovician of Bohemia. Alcheringa 25(2), 143-154. DOI 10.1080/03115510108619101

KREJČí, J. 1877. Geologie čili nauka o útvarech zemských se zvláštním ohledem na krajiny českoslovanské. $2^{\text {nd }}$ edition. 1035 pp. J. Krejčí, Praha.

KŘiž, J. 1969. Genus Butovicella Kř́žz̆, 1965 in the Silurian of Bohemia (Bivalvia). Sborník geologických věd, Paleontologie 10, 105-139.

Ǩ̌iž, J. 1974. Studium svalových systémů u recentnich mlžů se vztahy $k$ mlžưm paleozoickým (Muscle systems in the Recent Bivalvia and their relationships to the Paleozoic Bivalvia). 34 pp. MS, Final report of the project Evolution of the fossil organisms, its populations and communities in relation to the environment in the history of Earth, Archive of Ústřední ústav geologický, Praha.

Kř́̇̌, J. 1995. Coxiconchia Babin, 1966 from the Llanvirn of the Prague Basin (Bivalvia, Ordovician, Bohemia) and the function of some "accessoric" muscles in recent and fossil Bivalvia. Věstník Českého geologického ústavu 70(2), 45-50.

Ǩ̌iž, J. 1997. Poznámky k paleoekologii mlžů ordoviku pražské pánve. Zprávy o geologických výzkumech v roce 1996, $168-172$.

Křiž, J. 1999. Bivalvia dominated communities of Bohemian type from the Silurian and Lower Devonian carbonate facies, 229-252. In Boucot, A.J. \& Lawson, J.D. (eds) Final report, project Ecostratigraphy. Paleocommunities: A case study from the Silurian and Lower Devonian. 895 pp. Cambridge University Press, Cambridge.

KŘiž, J. \& Steinová (= Polechová), M. 2009. Uppermost Ordovician bivalves from the Prague Basin (Hirnantian, Perunica, Bohemia). Bulletin of Geosciences 84(3), 409-436.

DOI 10.3140/bull.geosci.1141

KuKaL, Z. 1962. Petrographical investigation of the Ordovician Šárka beds in the Barrandian area (English summary). Sborník Ústředního ústavu geologického, Geologie 27, 175-214.

KuKaL, Z. 1963. The results of the sedimentological investigation of the Ordovician in the Barrandian area (English summary). Sborník geologických věd, Geologie 1, 103-137.

Laptikhovsky, V.L., Rogov, M.A., Nikolaeva, S.E. \& ArkhiPKIN, A.I. 2013. Environmental impact on ectocochleate cephalopod reproductive strategies and the evolutionary significance of cephalopod egg size. Bulletin of Geosciences 88(1), 83-94. DOI 10.3140/bull.geosci.1351

LefeBvRE, B. 2007. Early Palaeozoic palaeobiogeography and palaeoecology of stylophoran echinoderms. Palaeogeography, Palaeoclimatology, Palaeoecology 245(1-2), 156-199. DOI 10.1016/j.palaeo.2006.02.021

Li, X. \& Droser, M.L. 1999. Lower and Middle Ordovician shell beds from the Basin and Range province of western United States (California, Nevada, and Utah). Palaios 14, 215-233. DOI $10.2307 / 3515435$

LILJEDAHL, L. 1994. Silurian nuculoid and modiomorphid bivalves from Sweden. Fossils and Strata 33(1), 1-89.

LinNé, C. 1758. Systema naturae per regna tria naturae, secundum classes, ordines, genera, species, cum characteribus, differentiis, synonymis, locis. Editio decima, reformata. 824 pp. Laurentii Salvii, Holmiae. DOI 10.5962/bhl.title.542

LiPold, M.V. \& KREJČí, J. 1860. Verhandlungen der kaiserlichköniglichen geologischen Reichsanstalt 11, 88-91.

Maillieux, E. 1939. L'Ordovicien de Sart-Bernard. Mémoire du Musée Royal d'Histoire naturelle 86, 1-59.

MandA, Š. 2008a. Trocholites Conrad, 1838 (Nautiloidea, Tarphycerida) in the Middle Ordovician of the Prague Basin and its palaeobiogeographical significance. Bulletin of Geosciences 83(3), 327-334.

DOI 10.3140/bull.geosci.2008.03.327

MANDA, Š. 2008b. Palaeoecology and palaeogeographic relations of the Silurian phragmoceratids (Nautiloidea, Cephalopoda) of the Prague Basin (Bohemia). Bulletin of Geosciences 83(1), 39-62. DOI 10.3140/bull.geosci.2008.01.039

MANDA, Š. \& FRÝDA, J. 2010. Silurian-Devonian boundary events and their influence on cephalopod evolution: evolutionary significance of cephalopod egg size during mass extinctions. Bulletin of Geosciences 85(3), 513-540.

DOI 10.3140/bull.geosci.1174

MAREK, L. 1966. New hyolithid genera from the Ordovician of Bohemia. Časopis Národního muzea, Oddíl př́rodovědný 135(2), 89-92.

MCAlester, A.L. 1965. Systematics, affinities and life habits of Babinka, a transitional Ordovician lucinoid bivalve. Palaeontology 8(2), 231-246.

McAlester, A.L. 1968. Type species of Paleozoic nuculoid bivalve genera. Memoir of the Geological Society of America 105, 1-143.

MCAlester, A.L. 1969. Palaeotaxodonta (Bivalvia), N227-N243. 
In Moore, R.C. (ed.) Treatise on Invertebrate Paleontology. Part N, Mollusca 6, Bivalvia. 487 pp. Geological Society of America \& University of Kansas Press, Boulder \& Lawrence.

Meek, F.B. \& Worthen, A.H. 1866. Descriptions of invertebrates from the Carboniferous System, Illinois. Geological Survey of Illinois 2,145-411.

Mergl, M. 2002. Linguliformean and craniiformean brachiopods of the Ordovician (Třenice to Dobrotivá Formations) of the Barrandian, Bohemia. Acta Musei nationalis Pragae, Series B 58(1-2), 1-82.

Mergl, M., FatKa, O. \& Budil, P. 2008. Lower and Middle Ordovician trilobite associations of Perunica: from shoreface endemicity to offshore uniformity (Prague Basin, Czech Republic), 275-282. In Rábano, I., Gozalo, R. \& GarcíaBELlido, D. (eds) Advances in trilobite research. Cuadernos del Museo Geominero 9. Instituto Geológico y Minero de España, Madrid.

MikULÁš, R. 1991. Trace fossils from siliceous concretions in the Šárka and Dobrotivá Formations (Ordovician, central Bohemia). Časopis pro mineralogii a geologii 36(1), 29-38.

MikULÁš, R. 2003. Trace fossils and bioturbation in the lower part of the Šárka Formation at Praha - Červený vrch Hill (Ordovician, Barrandian area, Czech Republic). Bulletin of Geosciences 78(2), 141-146.

MiLleR, S.A. 1889. North American geology and palaeontology for the use of amateurs, students and scientists. $664 \mathrm{pp}$. Western Methodist Book Concern, Cincinnati.

Morris, N.J. \& Fortey, R.A. 1976. The significance of Tironucula gen. nov. to the study of bivalve evolution. Journal of Paleontology 50(4), 701-709.

Murchison, R.I. 1859. Siluria. The history of the oldest fossiliferous rocks and their foundations, with a brief sketch of the distribution of gold over the earth. $3^{\text {rd }}\left[2^{\text {nd }}\right]$ edition. 592 pp. John Murray, London.

Nevesskaya, L.A., Scarlato, O.A., Starobogatov, Y.I. \& EberZIN, A.G. 1971. Novye predstavleniia o sisteme dvustvorchatykh molliuskov [New ideas on the systematics of bivalved mollusks]. Paleontologicheskii Zhurnal 1971(2), 3-20.

NovÁK, O. 1891. Revision der paläozoischen Hyolithiden Böhmens. Abhandlungen der Königlichen Böhmischen Gesellschaft der Wissenschaften 7(4), 1-48.

NÜTZEL, A. \& FRÝDA, J. 2003. Paleozoic plankton revolution: evidence from early gastropod ontogeny. Geology 31, 829-831. DOI 10.1130/G19616.1

PelseneER, P. 1889. Sur la classification phylogénétique de pélécypods. Bulletin Scientifique de la France et de la Belgique, $20[=$ sér. 3, 2] (1-4), 27-52.

Pfab, L. 1934. Revision der Taxodonta des böhmischen Silurs. Palaeontographica, Abteilung A 80, 195-253.

PhILliPs, J. 1848. The Malvern Hills compared with the Palaeozoic districts of Abberley, Woolhope, May Hill, Tortworth, and Usk. Memoirs of the Geological Survey, Great Britain, and of the Museum of Practical Geology in London 2(1), 1-330, with Palaeontological Appendix by J. Phillips and J.W. Salter, 331-386.

PojeTA, J. 1971. Review of Ordovician Pelecypods. United States Geological Survey Professional Papers 685, 1-46.

PojetA, J. 1978. The origin and early taxonomic diversification of Pelecypods. Royal Society of London Philosophical Transactions B 284, 225-246.
PojetA, J. 2007. Nucularcidae: a new family of palaeotaxodont Ordovician pelecypods (Mollusca) from North America and Australia. Canadian Journal of Earth Science 44, 1479-1501. DOI 10.1139/E07-028

Pojeta, J. \& Gilbert-Tomlinson, J. 1977. Australian Ordovician pelecypod molluscs. Bureau of Mineral Resources, Geology and Geophysics, Bulletin 174, 1-64.

PORTLOCK, J.E. 1843. Report on the geology of Londonderry and parts of Tyrone and Fermanagh. xxxi +784 pp. Dublin \& London.

Pर̌IBYL, A. 1966. Ostracodi českého ordoviku: Cerninella gen. nov. (Ostrakoden des böhmischen Ordoviziums: Cerninella gen. n.). Časopis Národního muzea, Oddíl př́rodovědný 135(4), 201-208.

RouAult, R. 1851. Mémoires sur le terrain paléozoïque des environs de Rennes. Bulletin de la Société géologique de France 8 , 358-399.

REID, R.G.B. 1990. Evolutionary implications of sulphide-oxidising symbioses in bivalves, 127-140. In Morton, B. (ed.) The bivalvia-Proceedings of a memorial symposium in honour of Sir Charles Maurice Yonge, Edinburgh 1986. Hong Kong University Press.

RƯŽIČKA, B. \& Prantl, F. 1960. Genotypy některých Barrandových rodů staroprvohorních mlžů (Pelecypoda). Časopis Národního muzea, Oddíl př́rodovědný 1960(1), 48-55. [in Czech, short English summary, p. 53]

SÁ, A. 2008. Moluscos del Ordovícico de la región de Trásos-Montes (Zona Centroibérica, NE de Portugal). Coloquios de Paleontología 58, 41-72.

SAlter, J.W. 1852. Note on the fossils above mentioned, from the Ottawa River. British Association Advance Science Report, $21^{\text {st }}$ meeting, 1851, Notices and Abstracts, etc., 63-65.

SALTER, J.W. 1859. Fossils from the base of the Trenton Group. Figures and descriptions of Canadian organic remains, Decade 1. 47 pp. Geological Survey of Canada, Montreal.

SÁnChEZ, T.M. 1990. Bivalvos del Ordovícico medio-Tardio de la Precordillera de San Juan (Argentina). Ameghiniana (Revista de la Asociación Paleontológica Argentina) 27(3-4), 251-261.

SÁNCHEZ, T.M. 1997. Additional mollusca (Bivalvia and Rostroconchia) from the Suri Formation, early Ordovician (Arenig), western Argentina. Journal of Paleontology 71(6), 1046-1054.

SÁncheZ, T.M. 1999. New late Ordovician (Early Caradoc) bivalves from the Sierra de villicum (Argentine Precordillera). Journal of Paleontology 73(1), 66-76.

SÁnCHEZ, T.M. 2005. New Bivalvia and Rostroconchia from the early Ordovician (late Tremadoc-middle Arenig) of northwestern Argentina. Journal of Paleontology 79(3), 532-541. DOI 10.1666/0022-3360(2005)079<0532:NBARFT>2.0.CO;2

SÁNCHEZ, T.M. 2008. The early bivalve radiation in the Ordovician Gondwanan basins of Argentina. Alcheringa 32, 223-246. DOI 10.1080/03115510802096044

Sánchez, T.M. \& Babin, C. 1994. Los Géneros Redonia y Catamarcaia (Mollusca, Bivalvia) de la Formación Suri (Ordovício temprano, oeste de Argentina) y su interés Paleobiogeográfico. Revista Española de Paleontología 9(1), 81-90.

SÁNChEZ, T.M. \& BABIN, C. 2003. Distribution paléogeographique des mollusques bivalves durant l'Ordovicien. Geodiversitas 25(2), 243-259. 
SÁncheZ, T.M. \& Babin, C. 2005. Lower Ordovician bivalves from southern Bolivia: palaeogeographic affinities. Ameghiniana 42(3), 559-566.

Sharpe, D. 1853. Description of the new species of Zoophyta and Mollusca, 146-158, Appendix B. In Ribeiro, C., Sharpe, D. \& JONES, T.R. On the Carboniferous and Silurian formations in the neighbourhood of Bussaco, Portugal. Quarterly Journal of the Geological Society of London 9, 135-161.

Soot-Ryen, H. 1969. A new species of Babinka (Bivalvia) from the lower Ordovician of Oland, Sweden. Palaeontology 12, 173-177.

Soot-Ryen, H. \& Soot-Ryen, T. 1960. The middle Ordovician of the Oslo region, Norway. Pelecypoda. Norsk Geologisk Tidsskrift 40(2), 81-122.

Starobogatov, Y.I. 1971. Systematic position of the Ordovician bivalve Babinka. Paleontological Journal 5, 84-387. [English translation by American Geological Institute, published 1972].

Steinová (= Polechová), M. 2012. Probable ancestral type of actinodont hinge in the Ordovician bivalve Pseudocyrtodonta Pfab, 1934. Bulletin of Geosciences 87(2), 333-346. DOI 10.3140/bull.geosci.1330

TAYLOR, J.D. \& GLOVER, E.A. 2000. Functional anatomy, chemosymbiosis and evolution of the Lucinidae. The Evolutionary Biology of the Bivalvia. Geological Society of London, Special Publications 177, 207-225.

Termier, G. \& Termier, H. 1950. Paléontologie Marocaine, II, Invertébrés de l'ère primaire, Fasc. 1, Foraminifères, spongiaires et coelentérés. Notes et Mémoire de Service Géologique du Maroc 73, 55-109.

Thoral, M. 1935. Contribution à l'étude paléontologique de l'Ordovicien inférieur de la Montagne Noire et révision sommaire de la faune cambrienne de la Montagne Noire. 362 pp. Imprimerie de la Charité, Montpellier.
Thorson, G. 1961. Length of pelagic larval life in marine bottom invertebrates as related to larval transport by ocean currents, 455-474. In SEARS, M. (ed.) Oceanography. American Association for the Advancement of Science, Freeman and Company, Washington.

TunNICLIFF, S.P. 1982. A revision of late Ordovician bivalves from Pomeroy, Co. Tyrone, Ireland. Palaeontology 25(1), 43-88.

UlRich, E.O. 1892. New Lamellibranchiata. American Geologist $10,96-104$.

Ulrich, E.O. \& SCOFIELD, W.H. 1894. The Lower Silurian Lamellibranchiata of Minnesota, 475-628. In ULRICH, E.O., Scofield, W.H., Clarke, J.M. \& Winchell, N.H. (eds) Final Report of the Geological and Natural History Survey of Minnesota, vol. 3, part 2, The Geology of Minnesota, Paleontology.

VANĚK, J. 1999. Ordovician in the easternmost part of the Prague Basin (Úvaly and Brandýs areas) and its comparison with the Rokycany area (westernmost part of the basin). Palaeontologia Bohemiae 5(2), 5-20.

VAVRDOVÁ, M. 1982. Phytoplankton communities of Cambrian and Ordovician age of Central Bohemia. Věstník Ústředního ústavu geologického 57(3), 145-155.

Vogel, K. 1962. Muscheln mit Schlosszihnen aus dem spanischen Kambrium und ihre Bedeutungftir die Evolution der Lamellibranchiaten. Akademie der Wissenschaften und der Literatur de mathematisch-naturwissenschaftlichen, Abhandlungen 4, 193-244.

VoKes, H.E. 1954. Some primitive fossil Pelycopoda and their possible significance. Journal of Washington Acadamy of Science 44, 233-236.

Yonge, C.M. 1939. The protobranchiate mollusca: A functional interpretation of their structure and evolution. Philosophical Transactions of the Royal Society of London 230(B), 79-147. 